\title{
DEBATA NAD NOWĄ STRATEGIĄ BEZPIECZEŃSTWA ZEWNĘTRZNEGO NA FORUM INSTYTUCJI I ORGANÓW UNII EUROPEJSKIEJ W LATACH 2012-2015
}

ABSTRACT Debate on the new strategy of external security at the forum of European Union institutions and bodies in 2012-2015

The subject of the article is the debate on the new external security strategy, which has been ongoing in the European Union since 2012. It presents the position of the European Council and the Council for Foreign Affairs, the European Commission, the European Parliament as well as the Interparliamentary Conference for a Common Foreign and Security Policy and Common Security and Defence Policy. In so far as these first two institutions play a decisive role in shaping a common security and defence policy, the influence of the next two is still limited, in spite of the fact that it has increased since the coming into force of the Lisbon Treaty of 13 December 2007. In turn, the Interparliamentary Conference, whose members include representatives of the European Parliament and national parliaments, functions only as an advisory body in this area.

Słowa kluczowe: strategia bezpieczeństwa zewnętrznego, traktat lizboński, wspólna polityka bezpieczeństwa i obrony, wspólna polityka zagraniczna i bezpieczeństwa, Rada Europejska, Rada do Spraw Zagranicznych, Komisja Europejska, Parlament Europejski, Konferencja Międzyparlamentarna ds. Wspólnej Polityki Zagranicznej i Bezpieczeństwa oraz Wspólnej Polityki Bezpieczeństwa i Obrony

Keywords: strategy of external security, Lisbon Treaty, common security and defence policy, common foreign and security policy, European Council, Council for Foreign Affairs, European Commission, European Parliament, 
Interparliamentary Conference for a Common Foreign and Security Policy and Common Security and Defence Policy

\section{UWAGI WSTĘPNE}

Nowe zagrożenia i kryzysy międzynarodowe w najbliższym i dalszym sąsiedztwie Unii Europejskiej, w szczególności agresja Rosji na Ukrainę (Krym) i wojna w Donbasie, które rozpoczęły się w 2014 r., oraz powstanie tzw. Państwa Islamskiego w tymże roku, dowiodły nie tylko słabości projektów Partnerstwa Wschodniego ${ }^{1}$ i Partnerstwa Środziemnomorskiego ${ }^{2}$ oraz nieskuteczności dyplomatycznych, cywilnych i militarnych instrumentów zarządzania kryzysami, ale w dramatyczny sposób unaoczniły również brak aktualnej i spójnej strategii w dziedzinie bezpieczeństwa zewnętrznego Unii ${ }^{3}$. Z kolei kryzys imigracyjny Unii Europejskiej, którego przebieg w 2015 r. stał się groźny nawet dla jej dalszej egzystencji, zastał Unię pozbawioną aktualnej strategii w zakresie bezpieczeństwa wewnętrznego. Opracowanie nowych dokumentów strategicznych w tych dwóch dziedzinach stało się zatem pilne jak nigdy wcześniej. Odtąd każda debata na temat zmian w strategii bezpieczeństwa zewnętrznego Unii była mocno powiązana z dyskusją o modyfikacji jej strategii bezpieczeństwa wewnętrznego. Obydwie strategie miały bowiem w tych nowych uwarunkowaniach międzynarodowych stanowić dwie strony tego samego medalu.

Przeszkodą w opracowaniu nowej strategii bezpieczeństwa zewnętrznego Unii Europejskiej było dotąd błędne przekonanie rządów większości państw członkowskich, że strategia bezpieczeństwa z 12 grudnia 2003 r., zmodyfikowana dokładnie pięć lat później, także w nowych warunkach międzynarodowych może być nadal aktualna ${ }^{4}$. Niektóre z nich zdecydowały się nawet na zacieśnienie bilateralnej współpracy wojskowej,

1 Szerzej na temat projektu Partnerstwa Wschodniego por.: A.K. Cianciara, Partnerstwo Wschodnie 2009-2014. Geneza, funkcjonowanie, uwarunkowania, Warszawa 2014.

2 Szerzej na temat projektu Partnerstwa Śródziemnomorskiego por.: Unia Europejska w regionie śródziemnomorskim. Między polityką wspólną a interesami państw cztonkowskich, red. J. Zając, Warszawa 2014.

3 Na temat pierwszych prób opracowania nowej strategii bezpieczeństwa zewnętrznego Unii Europejskiej w latach 2012-2013 por.: J.J. Węc, W poszukiwaniu nowej strategii bezpieczeństwa zewnętrznego Unii Europejskiej, „Krakowskie Studia Międzynarodowe” 2015, nr 2, s. 71-81. Szerzej na temat koncepcji reformy europejskiej strategii bezpieczeństwa Unii Europejskiej por.: W stronęnowej europejskiej strategii bezpieczeństwa. Food for thought, Biuro Bezpieczeństwa Narodowego,Warszawa 2012, [online] http://www.bbn.gov.pl, 25 IV 2016, s. 1-2; P. Olszewski, Reforma strategii bezpieczeństwa Unii Europejskiej jako nowe otwarcie w relacjach transatlantyckich. Koncepcja i perspektywy, [w:] System euroatlantycki w wielobiegunowym tadzie niędzynarodowym, red. J.M. Fiszer, P. Olszewski, Warszawa 2013, s. 208-229, System Euroatlantycki w Wielobiegunowym Świecie i Jego Perspektywy, 6.

4 Spotkanie Rady Europejskiej w Brukseli w dniach 11-12 grudnia 2003 r. Konkluzje prezydencji, Bruksela, 11-12 XII 2003 r., 16616/07, s. 89-90; Posiedzenie Rady Europejskiej w Brukseli w dniach 1112 grudnia 2008 r. Konkluzje prezydencji, Bruksela, 13 II 2009 r., 16616/07 (załącznik 2), s. 15-18; Rada Unii Europejskiej, Europejska Strategia Bezpieczeństwa „Bezpieczna Europa w lepszym świecie”, Urząd Publikacji Unii Europejskiej, Luksemburg 2009, s. 7-43. Analizę Europejskiej strategii bezpie- 
co stanowiło kolejną przyczynę braku zainteresowania uchwaleniem strategii dla całej Unii Europejskiej. Prace nad nowym dokumentem strategicznym utrudniał również zbiurokratyzowany proces podejmowania decyzji w Unii, prowadzący do opóźnień w realizacji zadań i celów wspólnej polityki bezpieczeństwa i obrony.

Przedmiotem artykułu jest debata na temat nowej strategii bezpieczeństwa zewnętrznego, jaka toczy się w Unii Europejskiej od 2012 r. Przedstawione w nim zostały stanowiska Rady Europejskiej i Rady do Spraw Zagranicznych, Komisji Europejskiej, Parlamentu Europejskiego oraz Konferencji Międzyparlamentarnej ds. Wspólnej Polityki Zagranicznej i Bezpieczeństwa oraz Wspólnej Polityki Bezpieczeństwa i Obrony. $\mathrm{O}$ ile te dwie pierwsze instytucje posiadają decydujące znaczenie w realizacji wspólnej polityki bezpieczeństwa i obrony (WPBiO), o tyle rola dwóch następnych jest nadal ograniczona, mimo iż wzrosła po wejściu w życie traktatu lizbońskiego z 13 grudnia 2007 r. ${ }^{5}$ Z kolei Konferencja Międzyparlamentarna, w skład której wchodzą przedstawiciele Parlamentu Europejskiego oraz parlamentów narodowych, jest jedynie organem doradczym w analizowanej dziedzinie ${ }^{6}$.

W pierwszej części artykułu przedstawiona zostanie debata instytucji i organów Unii Europejskiej na temat nowej strategii bezpieczeństwa zewnętrznego w latach 2012-2013, kiedy to podjęto w ogóle decyzję o konieczności jej opracowania i pierwszy raz od pięciu lat poświęcono tej sprawie dużo uwagi podczas posiedzenia Rady Europejskiej w grudniu 2013 r. Druga część pracy poświęcona będzie przygotowaniom do zapowiedzianego na czerwiec 2015 r. specjalnego posiedzenia Rady Europejskiej, podczas którego miało dojść do przyjęcia nowego dokumentu strategicznego Unii Europejskiej, ale głównie z powodu kryzysu imigracyjnego zamierzenia tego nie udało się zrealizować.

\section{PIERWSZA FAZA DEBATY W LATACH 2012-2013}

Debata na temat nowej strategii bezpieczeństwa zewnętrznego rozpoczęła się w Unii Europejskiej 23 lipca 2012 r. wraz z przyjęciem przez Radę do Spraw Zagranicznych

czeństwa z 2003 r., a także jej zmodyfikowanej wersji z 2008 r. por.: J.J. Węc, W poszukiwaniu nowej strategii..., s. 71-72.

$5 \quad$ Szerzej na ten temat por.: J.J. Węc, Traktat Lizboński. Polityczne aspekty reformy ustrojowej Unii Europejskiej w latach 2007-2015, Kraków 2016, s. 245, 251-253, Societas, 36.

6 Konferencja Międzyparlamentarna została ustanowiona w kwietniu 2011 r. w Brukseli na mocy art. 10 protokołu nr $1 \mathrm{w}$ sprawie roli parlamentów narodowych w Unii Europejskiej, załączonego do TUE, TFUE i TEWEA w wersji traktatu lizbońskiego. W jej skład wchodzi po sześciu posłów delegowanych przez parlamenty narodowe oraz szesnastu deputowanych Parlamentu Europejskiego. Zbiera się ona co sześć miesięcy w państwie sprawującym unijną prezydencję lub w siedzibie Parlamentu Europejskiego w Brukseli. Konferencja Międzyparlamenarna uchwala w drodze konsensu konkluzje polityczne, które nie są jednak wiążące ani dla parlamentów narodowych, ani dla Parlamentu Europejskiego, ani dla żadnej innej instytucji Unii Europejskiej. Por.: Regulamin Konferencji Międzyparlamentarnej ds. Wspólnej Polityki Zagranicznej i Bezpieczeństwa oraz Wspólnej Polityki Bezpieczeństwa i Obrony, [online] http://oide.sejm.gov.pl, 25 IV 2016, s. 1-4. 
pierwszych konkluzji w tej sprawie ${ }^{7}$. Mimo głównie technicznego charakteru miały one duże znaczenie polityczne. Zobowiązywały bowiem wysoką przedstawiciel Unii ds. zagranicznych i polityki bezpieczeństwa, Catherine Ashton, do rozpoczęcia, wraz z rządami państw członkowskich, debaty na temat „czynienia postępów” oraz wprowadzenia niezbędnych zmian w tej dziedzinie. Wskazywały również na inicjatywę przewodniczącego Rady Europejskiej, Hermana Van Rompuya, w sprawie przeprowadzenia w 2013 r. na forum tej instytucji dyskusji na temat obronności $i^{8}$. W oparciu o ten dokument Rada Europejska w swoich konkluzjach z 14 grudnia 2012 r. zobowiązała wysoką przedstawiciel Unii i Komisję Europejską do opracowania najpóźniej do września $2013 r$. sprawozdania zawierającego nowe propozycje dalszego rozwoju wspólnej polityki bezpieczeństwa i obrony. Miały one obejmować trzy następujące priorytety: po pierwsze, zwiększenie skuteczności, widoczności i wpływu WPBiO; po drugie, rozwój zdolności obronnych; po trzecie, wzmocnienie europejskiego przemysłu obronnego?.

24 lipca 2013 r. do debaty na temat zmian we wspólnej polityce bezpieczeństwa i obrony włączyła się Komisja Europejska, która opublikowała komunikat skierowany do Parlamentu Europejskiego, Rady Unii Europejskiej, Komitetu Ekonomiczno-Społecznego i Komitetu Regionów. Zwróciła ona uwagę na fakt, że wskutek kryzysu zadłużeniowego strefy euro państwa członkowskie radykalnie ograniczyły wydatki na obronność. I tak, w latach 2001-2010 wydatki te spadty z $251 \mathrm{mld}$ euro do $194 \mathrm{mld}$ euro. Cięcia objęły głównie inwestycje na badania i rozwój w dziedzinie obronności. Tylko w latach 2005-2010 budżet na europejskie badania i rozwój zmniejszył się o 14\%, osiągając poziom 9 mld euro. Oznaczało to, że dwadzieścia siedem państw członkowskich Unii Europejskiej przeznaczało wówczas łącznie na ten cel kwotę aż siedmiokrotnie mniejszą aniżeli USA. Mimo to Unia Europejska mogłaby - zdaniem Komisji Europejskiej - w dalszym ciągu odgrywać strategiczną rolę na arenie międzynarodowej, ponieważ dysponowała siłami zbrojnymi liczącymi łącznie we wszystkich państwach członkowskich 1,6 mln żołnierzy, a ich wydatki na obronę w 2011 r. były nadal większe aniżeli wydatki Chin, Rosji i Japonii razem wziętych ${ }^{10}$. Aby osiągnąć ten cel, Komisja Europejska zaproponowała realizację następujących zadań: po pierwsze, przestrzeganie i stosowanie obowiązującego dorobku prawnego, w szczególności dyrektywy Parlamentu Europejskiego i Rady z 6 maja 2009 r. w sprawie transferów produktów związanych z obronnością na rynku wewnętrznym oraz dyrektywy Parlamentu

Konkluzje polityczne Rady do Spraw Zagranicznych były na ogół przyjmowane po uprzedniej dyskusji na posiedzeniach Grupy Polityczno-Wojskowej, Komitetu ds. Aspektów Cywilnych Zarządzania Kryzysowego oraz Komitetu Politycznego i Bezpieczeństwa. Następnie zatwierdzał je COREPER II i uchwalała Rada do Spraw Zagranicznych.

8 Posiedzenia Rady do Spraw Zagranicznych w dniu 23 lipca 2012 r. Komunikat prasowy, Bruksela, 23 VII 2012 r., 12800/1/12 REV 1, s. 17-19.

9 Posiedzenie Rady Europejskiej w dniach 13-14 grudnia 2012 r. Konkluzje, Bruksela, 14 XII 2012 r., EUCO 205/12, s. 8-11.

10 Komisja Europejska, Komunikat Komisji do Parlamentu Europejskiego, Rady, Europejskiego Komitetu Ekonomiczno-Spotecznego i Komitetu Regionów „W kierunku bardziej konkurencyjnego i wydajnego sektora obronności i bezpieczeństwa”, Bruksela, 24 VII 2013 r., COM(2013) 542 wersja ostateczna, s. 3-4. 
Europejskiego i Rady z 13 lipca 2009 r. w sprawie zamówień publicznych w dziedzinie obronności ${ }^{11}$, co winno umożliwić pogłębienie rynku wewnętrznego w zakresie obrony i bezpieczeństwa; po drugie, ustanowienie europejskiej bazy technologiczno-przemysłowej sektora obronnego (European Defence Technological and Industrial Base EDTIB) w celu zwiększenia konkurencyjności przemysłu obronnego; po trzecie, ścisłe powiązanie ze sobą cywilnych i wojskowych aspektów bezpieczeństwa m.in. w celu wydajniejszego wykorzystania środków finansowych. Komisja Europejska zwróciła się również do szefów państw lub rządów o przedyskutowanie tych propozycji podczas posiedzenia Rady Europejskiej w grudniu 2013 r., wraz ze wspomnianym wyżej sprawozdaniem wysokiej przedstawiciel Unii w sprawie dalszego rozwoju wspólnej polityki bezpieczeństwa i obrony ${ }^{12}$.

Siedem tygodni później, 12 września 2013 r., Parlament Europejski uchwalił rezolucję poświęconą strukturom wojskowym Unii Europejskiej. Wyraził w niej głębokie zaniepokojenie z powodu niedostatecznej zdolności Unii do reagowania na kryzysy międzynarodowe, pomimo jej dtugoletniego zobowiazania do utrzymania pokoju i ochrony praw cztowieka, zapobiegania konfliktom i wzmocnienia bezpieczeństwa miedzynarodowego zgodnie z zasadami określonymi w Karcie Narodów Zjednoczonych ${ }^{13}$. Parlament podkreślił również, że $w$ interesie UE oraz państw cztonkowskich leży spójne dziatanie $w$ roli podmiotu zapewniającego bezpieczeństwo nie tylko w Europie, ale również w innych częściach świata, zaś szczególnie w krajach sasiadujacych. Zdaniem autorów rezolucji Unia Europejska winna być przygotowana do catościowego podejścia do zarządzania kryzysowego, obejmującego szeroki wachlarz środków dyplomatycznych, ekonomicznych, rozwojowych i w ostateczności wojskowych ${ }^{14}$. W ślad za tym wezwali oni rządy państw członkowskich do wypracowania kompromisu politycznego w sprawie utworzenia w petni sprawnej Kwatery Gtównej Operacji UE w ramach Europejskiej Stużby Dziatań Zewnętrznych, w razie konieczności za pośrednictwem stałej współpracy strukturalnej. Winna ona być odpowiedzialna za planowanie i prowadzenie misji cywilnych oraz wojskowych, posiadających oddzielne struktury dowodzenia. Utworzenie Kwatery Głównej Operacji UE znacznie zwiększytoby pamięć instytucjonalną UE w odniesieniu do zarządzania kryzysowego, a także przyczynitoby się do rozwoju wspólnej kultury strategicznej poprzez delegowanie pracowników krajowych $i$ maksymalizacji korzyści ptynacych z koordynacji cywilno-wojskowej. Ułatwiłoby również Parlamentowi

11 Dyrektywa Parlamentu Europejskiego i Rady 2009/43/WE z dnia 6 maja 2009 r. w sprawie uproszczenia warunków transferów produktów zwiąanych z obronnościa we Wspólnocie, „Dziennik Urzędowy Unii Europejskiej” L, 2009, nr 146, s. 1-36; Dyrektywa Parlamentu Europejskiego i Rady 2009/81/ WE $z$ dnia 13 lipca 2009 r. w sprawie koordynacji procedur udzielania niektórych zamówień na roboty budowlane, dostawy i ustugi przez instytucje lub podmioty zamawiajace $w$ dziedzinach obronności i bezpieczeństwa i zmieniająca dyrektywy 2004/17/WE i 2004/18/WE, „Dziennik Urzędowy Unii Europejskiej” L, 2009, nr 216, s. 76-136.

12 Komisja Europejska, Komunikat Komisji do Parlamentu Europejskiego, Rady, Europejskiego Komitetu Ekonomiczno-Spotecznego i Komitetu Regionów „W kierunku bardziej konkurencyjnego..., s. 5.

13 Parlament Europejski, Rezolucja Parlamentu Europejskiego z dnia 12 wrzé́nia 2013 r. w sprawie struktur wojskowych UE: stan obecny i przyszte perspektywy (2012(2319)INI)), P7_TA(2013)0381, s. 2.

14

Tamże. 
Europejskiemu oraz Radzie Unii Europejskiej sprawowanie nadzoru politycznego nad zarządzaniem kryzysowym ${ }^{15}$.

Parlament Europejski odniósł się także do problemu grup bojowych oraz zasad ich finansowania ${ }^{16}$. Wskazał na wkład grup bojowych w transformację sił zbrojnych państw członkowskich, wzmocnienie interoperacyjności wojskowej oraz promowanie współpracy wielonarodowej. $Z$ drugiej strony wyraził ubolewanie, że nie udało się dotąd ani razu wykorzystać grup bojowych jako instrumentu szybkiego reagowania, choć kryzys w Mali w 2013 r. stwarzał taką okazję ${ }^{17}$. W ślad za tym deputowani opowiedzieli się za modyfikacją składu grup bojowych w taki sposób, aby daną grupę tworzyły zasadniczo państwa tego samego regionu, podobnie postrzegające istniejące zagrożenia. Zwiększyłoby to bowiem prawdopodobieństwo osiągnięcia kompromisu i odpowiedniej reakcji na te zagrożenia. Deputowani wyrazili również opinię, że stosowanie zasady przypisania kosztów do miejsca ich powstania w odniesieniu do grup bojowych stawianych $w$ stan gotowości w sposób dobrowolny i rotacyjny jest sprzeczne z zasada sprawiedliwego podziatu obciązeń. W związku z tym wezwali wysoką przedstawiciel Unii do przedstawienia wniosku mającego na celu dostosowanie mechanizmu ATHE$\mathrm{NA}^{18}$ do specyfiki grup bojowych, w razie potrzeby w ramach stałej współpracy strukturalnej, a także wniosku w sprawie utworzenia i finansowania funduszu początko-

15 Tamże, s. 4. Gdy w 2011 r. polska prezydencja w Unii Europejskiej próbowała ustanowić stałe dowództwo planowania i prowadzenia operacji cywilno-wojskowych, napotkała sprzeciw Wielkiej Brytanii, która argumentowała, że utworzenie takiego dowództwa byłoby zbyt kosztowne i konkurencyjne wobec NATO. Później już nigdy nie udało się osiągnąć konsensu w tej sprawie, w związku z czym Unia jest nadal pozbawiona jednego centrum dowodzenia operacjami cywilnymi i wojskowymi. Por.: J.J. Węc, Pierwsza polska prezydencja w Unii Europejskiej. Uwarunkowania, procesy decyzyjne, osiagnięcia i niepowodzenia, Kraków 2012, s. 233, Societas, 44.

16 Grupy bojowe (Battlegroups) to związki taktyczno-bojowe Unii Europejskiej, mające charakter sił szybkiego reagowania. W lutym 2004 r. w obliczu trudności z utworzeniem Europejskiego Korpusu Sił Szybkiego Reagowania, w skład którego miało wchodzić piętnaście brygad (50-60 tys. żołnierzy), Francja, Niemcy i Wielka Brytania zaproponowały ustanowienie grup bojowych. 6 kwietnia 2004 r. ministrowie obrony państw członkowskich zaakceptowali tę propozycję, zaś 22 listopada tegoż roku podczas czwartej konferencji planistycznej ustalili, że grupy bojowe winny prowadzić wszystkie rodzaje misji petersberskich i osiągać gotowość do działania w ciągu od trzydziestu do stu dwudziestu dni. Szerzej na ten temat por.: A. Ciupiński, Zdolności wojskowe Unii Europejskiej. Perspektywy grup bojowych, „Rocznik Integracji Europejskiej” 2014, nr 8, s. 105-115, [online] http://dx.doi.org/10.14746/ rie.2014.8.8; G. Lindstrom, Enter the EU Battlegroups, Paris 2007, Chaillot Papers, 97. Pierwsze grupy bojowe zostały utworzone w $2007 \mathrm{r}$. Miały one być motorem transformacji narodowych sił zbrojnych państw członkowskich Unii Europejskiej. Winny również umożliwić Unii Europejskiej samodzielną reakcję na kryzysy regionalne czy też inną sytuację wymagającą zaangażowania sił o charakterze ekspedycyjnym w jej sąsiedztwie. Pierwszy cel został osiągnięty jedynie częściowo, zaś drugi nie doczekał się dotąd realizacji.

17 Na temat przyczyn niewykorzystania wtedy grup bojowych por.: A. Ciupiński, Zdolności wojskowe..., s. 114.

18 Mechanizm ATHENA został ustanowiony na mocy decyzji Rady Unii Europejskiej z 23 II 2004 r. w celu finansowania kosztów operacji wojskowych i polityczno-obronnych. Por.: Council Decision 2004/197/CFSP of 23 February 2004 establishing a mechanism to administer the financing of the common costs of European Union operations having military or defence implications, Official Journal L, 2004, nr 63, s. 68-82. 
wego ${ }^{19}$. W tym kontekście zwrócili uwagę, że wszelkimi kosztami niezwiązanymi z operacjami wojskowymi (np. koszty przygotowania grup bojowych $i$ ich pozostawania w gotowości) można by obciążý budżet ogólny Unii Europejskiej ${ }^{20}$.

Nawiązując do sprawy wielonarodowych sił zbrojnych pozostających poza Unią Europejską, Parlament opowiedział się za zacieśnieniem współpracy między Eurokorpusem a Sztabem Wojskowym UE oraz za akcesją do Eurokorpusu innych państw członkowskich Unii ${ }^{21}$. Mogłoby to być zaczątkiem w petni zintegrowanego elementu europejskich sit zbrojnych ${ }^{22}$. Jeśli chodzi natomiast o relacje pomiędzy Unią Europejską a NATO, to Parlament wyraził opinię, że wzmocnienie europejskich zdolności wojskowych Unii nie koliduje z interesami NATO, ponieważ może się przyczynić do bardziej sprawiedliwego podziatu obciążén w ramach sojuszu. Siły reagowania NATO i grupy bojowe Unii Europejskiej winny się zatem wzajemnie uzupełniać. Dlatego należy podjąć działania na rzecz wzmocnienia synergii między nimi. Parlament zaproponował również bardziej regularną współpracę na szczeblu politycznym między wysoką przedstawiciel Unii a sekretarzem generalnym NATO w celu usprawnienia zarządzania zasobami oraz realizacji operacji zarówno cywilnych, jak i wojskowych. Wskazał także na konieczność rozwijania istniejących ram współpracy operacyjnej pomiędzy Unią Europejską a NATO, począwszy od porozumień „Berlin plus”23, których wdrażanie $w$ dalszym ciagu jest zablokowane przez Turcję ${ }^{24}$.

19 Fundusz początkowy to nowy instrument finansowy ustanowiony w traktacie lizbońskim, z którego winny być pokrywane koszty na działania przygotowawcze do misji petersberskich (art. 41 ust. 3 TUE).

20 Parlament Europejski, Rezolucja Parlamentu Europejskiego z dnia 12 września 2013 r. ... s. 4-5.

21 Korpus Europejski (Eurokorpus) został ustanowiony w 1993 r. z inicjatywy Niemiec i Francji. Następnie przystąpiły do niego Belgia, Luksemburg i Hiszpania. Zdolność operacyjną uzyskał w 1995 r. Wchodził w skład „sił podległych” Unii Zachodnioeuropejskiej, gdzie miał być wykorzystywany do realizacji misji petersberskich, ale z drugiej strony podlegat też NATO, będąc tam zobowiązanym do działań obronnych na podstawie art. 5 traktatu waszyngtońskiego z 4 kwietnia 1949 r. Por.: A. Ciupiński, Zdolności wojskowe..., s. 105.

22 Parlament Europejski. Rezolucja Parlamentu Europejskiego z dnia 12 września 2013 r. ..., s. 8. Należy w tym kontekście podkreślić, że art. 42 ust. 3 TUE w wersji traktatu lizbońskiego przewiduje możliwość oddania przez państwa członkowskie do dyspozycji Unii ich „zdolności” cywilnych i wojskowych, aby przyczynić się do osiagnięcia celów określonych przez Radę. Dotyczy to także państw wspólnie powołujących siły wielonarodowe, które mogą być przekazane Unii Europejskiej. Ponieważ artykuł ten nie zawiera jednak przepisu upoważniającego Radę Europejską lub Radę Unii Europejskiej, nie można dokonać jego implementacji, a to oznacza, że decyzje w tej sprawie są zastrzeżone wyłącznie dla państw członkowskich. Por.: J.J. Węc, Dynamika wspólnej polityki bezpieczeństwa i obrony po wejściu w życie traktatu lizbońskiego, [w:] Bezpieczeństwo międzynarodowe. Polska, Europa, Świat. Księga Jubileuszowa dedykowana Profesorowi Ryszardowi Ziębie z okazji czterdziestolecia pracy naukowej, red. J. Zając, A. Włodkowska-Bagan, M. Kaczmarski, Warszawa 2015, s. 439-440.

23 W 1996 r. w Berlinie ministrowie spraw zagranicznych państw członkowskich NATO zgodzili się utworzyć w ramach NATO Europejską Tożsamość Bezpieczeństwa i Obrony (tzw. europejski filar NATO). W 2003 r. przedstawiciele NATO i Unii Europejskiej podpisali natomiast pakiet porozumień, które zaczęto odtąd nazywać porozumieniami „Berlin plus”. Ich podstawowym postanowieniem była możliwość korzystania przez Unię z sił i zasobów militarnych NATO w czasie prowadzenia własnych operacji wojskowych, w których NATO nie zamierza uczestniczyć. I tak, 12 III 2003 r. podpi- 
W debacie na temat nowej strategii bezpieczeństwa zewnętrznego Unii Europejskiej wzięła także udział Konferencja Międzyparlamentarna ds. Wspólnej Polityki Zagranicznej i Bezpieczeństwa oraz Wspólnej Polityki Bezpieczeństwa i Obrony jako forum złożone z przedstawicieli Parlamentu Europejskiego i parlamentów narodowych. Już podczas posiedzenia w dniach 4-6 września 2013 r. w Wilnie przyjęła ona konkluzje polityczne dotyczące prac nad nową strategią. Wyraziła w nich opinię, że parlamenty narodowe i Parlament Europejski winny być w jak największym stopniu zaangażowa$n e \mathrm{w}$ proces konceptualizacji i formułowania takiej strategii. Wezwała Radę Europejską, aby podczas zbliżającego się w grudniu 2013 r. posiedzenia poświęconego analizowanej kwestii data [ona] jakże potrzebny impuls do przeciwdziatania poważnemu pogorszeniu sięstanu obronności $w$ Europie oraz przedstawiła propozycje dotyczące zmian we wspólnej polityce bezpieczeństwa i obrony, w szczególności w zakresie usprawnienia procesu podejmowania decyzji związanych z WPBiO, finansowania misji cywilnych i wojskowych, wykorzystania stałej współpracy strukturalnej i przyszłości grup bojowych ${ }^{25}$. Zwróciła uwagę na fakt, że grupy bojowe mogłyby się stać jednymi z najważniejszych instrumentów WPBiO, ale pod warunkiem lepszego określenia ich przydatności, na przyktad poprzez przyjęcie modutowego rozwiazania, potożenie większego nacisku na szkolenia, ćwiczenia $i$ certyfikacje, usprawnianie planowania oraz zapewnienie równiejszego podziatu obciażeñ ${ }^{26}$. Opowiedziała się także za ściślejszą współpracą pomiędzy Unią Europejską a NATO w zakresie planowania obrony, w szczególności za synchronizacją i harmonizacją unijnego planu rozwoju potencjału militarnego z procesem planowania obrony NATO. Pozwoliłoby to bowiem uniknąć dublowania się działań podejmowanych w tym zakresie przez obie strony ${ }^{27}$.

Ponad dwa miesiące później, 21 listopada 2013 r., w rezolucji poświęconej wdrażaniu wspólnej polityki bezpieczeństwa i obrony Parlament Europejski ponownie zwrócił uwagę na poważne i nieustanne zmiany w środowisku geopolitycznym, które charakteryzuja wielowymiarowe i asymetryczne zagrożenia, międzynarodowy terroryzm, wzrost wschodzacych potęg oraz strategiczny zwrot Stanów Zjednoczonych ku rejonowi Pacyfi-

sano porozumienie w sprawie bezpieczeństwa informacji niejawnych, zaś 17 III tegoż roku zawarto dalsze cztery umowy, gwarantujące: zapewnienie Unii Europejskiej dostępu do planowania operacyjnego NATO; udostępnienie Unii zdolności i zasobów militarnych NATO; adaptację systemu planowania obronnego NATO do realizacji operacji Unii, a także „europejskie opcje dowodzenia” w ramach NATO dla operacji prowadzonych przez Unię. Por.: Ministerstwo Spraw Zagranicznych RP, Relacje UE-NATO, s. 1, [online] https://www.msz.gov.pl/pl/; Instytucjonalne relacje UE-NATO, 25 IV 2016, s. 1-2, [online] http://www.psz.pl/; M. Terlikowski, Stan i perspektywy partnerstwa UE i NATO, 25 IV 2016, „Biuletyn PISM” 2010, nr 106, s. 1-2.

24 Parlament Europejski, Rezolucja Parlamentu Europejskiego z dnia 12 września 2013 r...., s. 9-10. Turcja nie zgadza się na zawarcie przez Cypr technicznego porozumienia o wymianie informacji niejawnych z NATO, ale z drugiej strony Cypr blokuje przystąpienie Turcji do EAO.

25 Posiedzenie Konferencji Międzyparlamentarnej ds. Wspólnej Polityki Zagranicznej i Bezpieczeństwa oraz Wspólnej Polityki Bezpieczeństwa i Obrony w dniach 4-6 września 2013 r. w Wilnie. Konkluzje, Wilno, 4-6 IX 2013 r., s. 5-6.

26 Tamże, s. 6.

27 Tamże. 
ku, więssze ubóstwo, gtód i niestabilność w potudniowym sasiedztwie UE, rosnące wyzwania w obszarze bezpieczeństwa morskiego, rozprzestrzenianie broni masowego rażenia i wzrost nielegalnego handlu bronia strzelecka i lekka, wyzwania w obszarze bezpieczeństwa energetycznego, poważna systemowa niewydolność finansowa oraz dotkliwy w skutkach i dtugotrwaty kryzys finansowy i gospodarczy majacy istotny wptyw na PKB wielu panstw cztonkowskich UE, a tym samym na krajowe budzety na obrone państw po obu stronach Atlantyku ${ }^{28}$. Z drugiej strony w obliczu zmian geopolitycznych w świecie wzrastała rola Europy, co oznaczało - zdaniem deputowanych do Parlamentu Europejskiego - że państwa członkowskie Unii Europejskiej winny wykazać więcej woli politycznej w celu uczynienia z Unii istotnego podmiotu na arenie międzynarodowej i gwaranta bezpieczeństwa, dysponującego autentyczną „autonomią strategiczną”. W związku z tym bardzo pozytywnie deputowani do Parlamentu Europejskiego przyjęli decyzję Rady Europejskiej o przeprowadzeniu w grudniu 2013 r. debaty nad wspólną polityką bezpieczeństwa i obrony, a także nad trzema wspomnianymi wyżej priorytetami politycznymi w tej dziedzinie, określonymi przez Radę Europejską w grudniu 2012 r. ${ }^{29}$

W rezolucji Parlamentu Europejskiego zwrócono również uwagę na ciągle niewykorzystany przez Unię Europejską potencjał zawarty w przepisach traktatu lizbońskiego dotyczących wspólnej polityki bezpieczeństwa i obrony. W tym kontekście wskazano w pierwszej kolejności na postanowienia traktatu dotyczące: po pierwsze, mechanizmu stałej współpracy strukturalnej między państwami członkowskimi (art. 46 ust. 6 TUE); po drugie, możliwości powierzenia grupie państw członkowskich realizacji misji petersberskich (art. 42 ust. 5 i art. 44 ust. 1 TUE); po trzecie, ustanowienia funduszu początkowego na działania przygotowawcze do tychże misji (art. 41 ust. 3 TUE); po czwarte, klauzuli solidarności (art. 222 TFUE); po piąte, klauzuli sojuszniczej (klauzuli o wzajemnej obronie), której zastosowanie wymagałoby jednak zapewnienia jasnej operacyjnej wyktadni przez szefów państw lub rządów (art. 42 ust. 7 TUE) ${ }^{30}$.

Przedmiotem krytyki był także dotychczasowy system finansowania wspólnej polityki bezpieczeństwa i obrony, oparty na zasadzie, że poszczególne państwa samodzielnie finansują swój udział w operacjach (costs lie where they fall). Zdaniem Parlamentu Europejskiego stosowanie tej zasady prowadzi do opóźnień lub catkowitych zastojów w procesie decyzyjnym dotyczącym zwłaszcza szybkiego rozmieszczenia grup bojowych ${ }^{31}$. W związku z tym Parlament sformułował następujące zalecenia dla rządów państw członkowskich: ustanowienie „unijnego mechanizmu” finansowania działalności grup bojowych, opartego na sprawiedliwym podziale obciążeń $w$ celu zapewnienia im realnego funkcjonowania w przysztości; nadanie Europejskiej Służbie Działań Zewnętrznych (ESDZ) uprawnień do sprawowania kontroli nad instrumentami finansowymi

28 Parlament Europejski, Rezolucja Parlamentu Europejskiego $z$ dnia 21 listopada 2013 r. w sprawie wdrażania wspólnej polityki bezpieczeństwa i obrony (na podstawie sprawozdania rocznego Rady dla Parlamentu Europejskiego na temat wspólnej polityki zagranicznej i bezpieczeństwa (14605/1/20122013/2105(INI)), P7_TA(2013)0513,s.3.

29 Tamże.

30 Tamże, s. 4-5.

$31 \quad$ Tamże, s. 7. 
Unii Europejskiej w dziedzinie zarządzania kryzysowego; wykorzystanie mechanizmu ATHENA do pokrywania wydatków związanych z realizacją operacji i misji WPBiO, a także ustanowienie funduszu początkowego $w$ celu zapewnienia szybkiego finansowania pilnych zadan'32.

Już w dniach 18-19 listopada 2013 r. Rada do Spraw Zagranicznych podczas posiedzenia w składzie ministrów spraw zagranicznych i obrony przeprowadziła debatę na temat niezbędnych zmian we wspólnej polityce bezpieczeństwa i obrony ${ }^{33}$. Przyjęte wówczas ustalenia miały stanowić punkt wyjścia do podjęcia stosownych decyzji przez Radę Europejską w grudniu 2013 r. Ponadto Rada do Spraw Zagranicznych zatwierdziła notę o zdolnościach Unii Europejskiej do szybkiego reagowania oraz wykorzystania w tym celu unijnych grup bojowych. Uczestnicy posiedzenia postanowili również przedłużyć do końca $2014 \mathrm{r}$. dotychczasowe ustalenia w sprawie zasad finansowania dodatkowych kosztów transportu zwiazanych z rozmieszczeniem w krótkim czasie grup bojowych drogą ląowa, morską ipowietrznq we wspólnym obszarze operacji34. Uzgodniono także, że pod „pewnymi warunkami” koszty te będą mogły być pokrywane ze środków mechanizmu ATHENA ${ }^{35}$.

11 grudnia 2013 r. Komisja Europejska i wysoka przedstawiciel Unii opublikowały wspólny komunikat skierowany do Parlamentu Europejskiego i Rady Unii Europejskiej w sprawie kompleksowego podejścia Unii do zewnętrznych konfliktów i sytuacji kryzysowych. W komunikacie stwierdzono, że Unia prowadzi politykę w wielu dziedzinach $i$ dysponuje wieloma instrumentami z zakresu dyplomacji, bezpieczeństwa, obrony, finansów, handlu, wspótpracy na rzecz rozwoju i pomocy humanitarnej, a instrumenty te umożliwiają jej skuteczne reagowanie na tego typu wyzwania. Jest ona też największym partnerem handlowym na świecie, zaś jej państwa członkowskie są łącznie największym darczyńca pomocy humanitarnej i oficjalnej pomocy rozwojowej. ${ }^{36}$.

Kompleksowe podejście Unii do zewnętrznych konfliktów i sytuacji kryzysowych winno jednak polegać nie tylko na skoordynowanym wykorzystaniu unijnych instrumentów i zasobów, ale także na wspólnej odpowiedzialności podmiotów szczebla unijnego i panstw cztonkowskich. Strategiczne połączenie tych podmiotów pozwoliłoby Unii Europejskiej na lepsze definiowanie i obronę jej podstawowych interesów, promowanie kluczowych celów politycznych, zapobieganie kryzysom oraz przyczynianie się do przywracania stabilności w zagrożonych regionach. Współpraca wszystkich instytucji

\section{Tamże, s. 7-8.}

33 Posiedzenia Rady do Spraw Zagranicznych w dniach 18-19 listopada 2013 r. Komunikat prasowy, Bruksela, 19 XI 2013 r., 16364/13, s. 12.

34 Ustalenia w sprawie finansowania kosztów transportu strategicznego grup bojowych były corocznie prolongowane, choć żadna z grup bojowych nie została dotąd wykorzystana w praktyce. W listopadzie 2015 r. Rada przedłużyła obowiązywanie tych uzgodnień do końca $2016 \mathrm{r}$.

35 Posiedzenia Rady do Spraw Zagranicznych w dniach 18-19 listopada 2013 r. ..., s. 16.

36 Komisja Europejska, Wysoki Przedstawciel Unii Europejskiej do spraw Zagranicznych i Polityki Bezpieczeństwa, Wspólny komunikat do Parlamentu Europejskiego i Rady „Kompleksowe podejście UE do zewnętrznych konfliktów i sytuacji kryzysowych", Bruksela, 11 XII 2013 r., JOIN(2013) 30 wersja ostateczna, s. 4. 
Unii Europejskiej i państw członkowskich na podstawie wspólnej analizy strategicznej i wspólnej wizji sprawiłaby, że Unia stałaby się silniejsza, a jej działania bardziej spójne, widoczne i skuteczne. Na tym właśnie winna polegać istota kompleksowego podejścia. W miarę wzrostu liczby wyzwań globalnych podejście takie staje się przecież coraz bardziej niezbędne. Winno ono się opierać na pełnym poszanowaniu następujących regut: po pierwsze, pomoc humanitarna udzielana być powinna na zasadach humanitaryzmu, neutralności, bezstronności i niezależności, wytącznie na podstawie potrzeb dotkniętej kryzysem ludności, zgodnie z konsensusem europejskim w sprawie pomocy humanitarnej z 18 grudnia 2007 r.; po drugie, pomoc rozwojowa winna być udzielana zgodnie z założeniami określonymi w konsensusie europejskim w sprawie rozwoju z 22 listopada 2005 r., konkluzjami Rady Unii Europejskiej w sprawie rozwoju z 14 maja 2012 r. (Programie działań na rzecz zmian) oraz wytycznymi Komitetu Pomocy Rozwojowej OECD; po trzecie, państwa członkowskie Unii Europejskiej, za pośrednictwem Komitetu Politycznego i Bezpieczeństwa, winny sprawować kontrolę polityczną i dowództwo strategiczne nad misjami i operacjami WPBiO. Ponadto wysoka przedstawiciel Unii i Komisja Europejska zapowiedziały, że we współpracy z państwami członkowskimi w najbliższych latach propozycje zawarte $\mathrm{w}$ analizowanym komunikacie winny być zrealizowane ${ }^{37}$.

W takiej atmosferze w dniach 19-20 grudnia 2013 r. zwołano w Brukseli pierwsze od pięciu lat posiedzenie Rady Europejskiej poświęcone w bardzo szerokim zakresie wspólnej polityce bezpieczeństwa i obrony. W przyjętych wówczas konkluzjach Rada Europejska stwierdzała, że skuteczność tej polityki winna polegać na tym, aby Unia Europejska szybko reagowała na zmieniające się warunki strategiczne i geopolityczne w Europie. Wymagałoby to m.in. zwiększenia wydatków budżetowych na obronność oraz konsolidacji europejskich rynków obronnych. W związku z tym Rada Europejska podjęła zobowiązanie na rzecz dalszego rozwoju współpracy państw członkowskich w tej dziedzinie, zgodnie z przepisami i możliwościami wynikającymi $\mathrm{z}$ traktatu lizbońskiego. Wezwała również państwa członkowskie do zwiększenia potencjatu umożliwiajacego prowadzenie misji i operacji cywilnych oraz wojskowych poprzez ustanowienie $\mathrm{EDTIB}^{38}$.

W ślad za konkluzjami Rady Europejskiej z grudnia 2012 r. doprecyzowane zostały rówież trzy działania priorytetowe, wyznaczające kierunek zmian we wspólnej polityce bezpieczeństwa i obrony ${ }^{39}$. W ramach tychże priorytetów Rada Europejska zapowiedziała realizację szczegółowych inicjatyw. Jeśli chodzi o pierwszy priorytet, czyli zwiększenie skuteczności, widoczności i wpływu wspólnej polityki bezpieczeństwa i obrony, postanowiono m.in.: wzmocnić koordynację działań pomiędzy instytucjami i organami WPBiO oraz przestrzeni wolności, bezpieczeństwa i sprawiedliwo-

Tamże, s. 3-4.

38 Posiedzenie Rady Europejskiej w dniach 19-20 grudnia 2013 r. Konkluzje, Bruksela, 20 XII 2013 r., EUCO 217/13, s. 1-2. 
ści (PWBiS $)^{40} \mathrm{w}$ celu skuteczniejszego zwalczania nielegalnej imigracji, przestępczości zorganizowanej i terroryzmu; udoskonalić system finansowania misji cywilnych i wojskowych Unii na podstawie kolejnego sprawozdania wysokiej przedstawiciel Unii, w tym także przeprowadzić zmiany w funkcjonowaniu mechanizmu ATHENA; zacieśnić współpracę w zakresie bezpieczeństwa energetycznego; przyjąć przepisy ramowe dla rozwoju cyberobrony w oparciu o wniosek wysokiej przedstawiciel Unii, przygotowany we współpracy z Komisją Europejską oraz Europejską Agencją Obrony (EAO) (w 2014 r.), a także uchwalić strategię w zakresie bezpieczeństwa morskiego Unii na podstawie wspólnego komunikatu Komisji Europejskiej i wysokiej przedstawiciel Unii

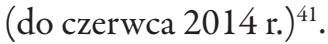

Odnosząc się do drugiego działania priorytetowego, czyli silniejszego rozwoju cywilnych i wojskowych zdolności obronnych, Rada Europejska zaakceptowała realizowane już wcześniej przez niektóre państwa członkowskie wspólne projekty wojskowe dotyczące m.in. rozwijania zdolności samolotów do tankowania w powietrzu, rozpoczęcia prac przygotowawczych do produkcji nowej generacji satelitów telekomunikacyjnych, współpracy w dziedzinie cyberbezpieczeństwa, a także stworzenia bezzałogowych systemów powietrznych w latach 2020-2025. Wezwała ona również wysoką przedstawiciel Unii oraz EAO do wypracowania do końca 2014 r. ram współpracy pomiędzy Unią Europejską a NATO, które winny być spójne z obecnymi procesami planowania NATO. Ponadto Rada Europejska pozytywnie oceniła kodeks postępowania w zakresie wspólnego pozyskiwania i wykorzystywania zdolności wojskowych opracowany przez EAO oraz zobowiązała ją do przedstawienia do końca 2014 r. sprawozdania na temat współpracy państw członkowskich w realizacji projektów dotyczących łączonych zamówieńt ${ }^{42}$.

Biorąc pod uwagę trzecie działanie priorytetowe, czyli rozwój przemysłu obronnego, Rada Europejska wskazała m.in. na potrzebę ustanowienia EDTIB; efektywniejszego wykorzystania funduszy Komisji Europejskiej z programu Horyzont 2020 do finansowania badań nad technologiami obronnymi (cywilnymi i wojskowymi); zwiększenia dostępu małych i średnich przedsiębiorstw do rynków uzbrojenia, a także obniżenia kosztów certyfikacji dla sprzętu obronnego ${ }^{43}$.

Rada Europejska zobowiązała także wysoką przedstawiciel Unii, aby we współpracy z Komisją Europejską i po konsultacjach z rządami państw członkowskich przedłożyła Radzie do Spraw Zagranicznych w 2015 r. sprawozdanie na temat globalnych i regionalnych wyzwań stojących przed Unią Europejską oraz możliwości przeciwdziałania tymże wyzwaniom. Na czerwiec 2015 r. zapowiedziała również dokonanie przeglądu stanu zaawansowania prac nad wszystkimi wymienionymi zadaniami ${ }^{44}$.

40 Pojęcie przestrzeni wolności, bezpieczeństwa i sprawiedliwości obejmuje sześć polityk odpowiedzialnych za bezpieczeństwo wewnętrzne Unii Europejskiej. Są to polityki: wizowa, azylowa, imigracyjna, współpraca sądowa w sprawach cywilnych, współpraca sądowa w sprawach karnych i współpraca policyjna.

41 Posiedzenie Rady Europejskiej w dniach 19-20 grudnia 2013 r. Konkluzje, s. 3-4.

42 Tamże, s. 5-7.

43 Tamże, s. 7-10.

44 Tamże, s. 4, 10. 
Zapowiedź opracowania, a następnie przedłożenia w 2015 r. raportu na temat możliwości przeciwdziałania przez Unię Europejską wyzwaniom globalnym i regionalnym, a także dokonania przeglądu prac nad zmianami w WPBiO otwierały możliwość opracowania nowej europejskiej strategii bezpieczeństwa zewnętrznego Unii. Wówczas wydawało się, że prace te zostaną zapoczątkowane właśnie podczas posiedzenia Rady Europejskiej w czerwcu 2015 r.

\section{DRUGA FAZA DEBATY W LATACH 2014-2015}

Do drugiej fazy debaty na temat opracowania nowej strategii bezpieczeństwa zewnętrznego Unii włączyła się jako pierwsza Konferencja Międzyparlamentarna ds. Wspólnej Polityki Zagranicznej i Bezpieczeństwa oraz Wspólnej Polityki Bezpieczeństwa i Obrony. W konkluzjach przyjętych podczas posiedzenia w dniach 3-4 kwietnia 2014 r. w Atenach pozytywnie oceniła ona decyzje Rady Europejskiej z grudnia 2013 r. w sprawie dalszych prac nad nową strategią bezpieczeństwa zewnętrznego. Określiła je jako niezbędny i długo wyczekiwany krok w kierunku zapewnienia skoordynowanego podejścia do europejskiej obrony ${ }^{45}$. Wezwała do realizacji wytyczonych zadań, aby podczas następnego posiedzenia Rady Europejskiej w czerwcu 2015 r., poświęconego wspólnej polityce bezpieczeństwa i obrony, udało się przyjąć nową strategię. W obliczu pojawienia się tuku niestabilności rozciagajacego się od Ukrainy przez pótnocna Afrykę strategiczna koordynacja działań Unii Europejskiej w dziedzinie wspólnej polityki bezpieczeństwa i obrony była - jej zdaniem - niezbędna bardziej niż kiedykolwiek wcześniej. Dlatego też Konferencja Międzyparlamentarna pozytywnie oceniła wspólny komunikat Komisji Europejskiej i wysokiej przedstawiciel Unii z 11 grudnia 2013 r. w sprawie kompleksowego podejścia UE do zewnętrznych konfliktów i sytuacji kryzysowych oraz zaleciła szybką realizację zawartych w nim celów ${ }^{46}$.

24 czerwca 2014 r. Rada do Spraw Zagranicznych, działając zgodnie ze zobowiązaniami wynikającymi z konkluzji Rady Europejskiej z grudnia 2013 r., uchwaliła strategię bezpieczeństwa morskiego Unii Europejskiej, zaś niespełna miesiąc później przyjęła do wiadomości sprawozdanie wysokiej przedstawiciel Unii i jednocześnie szefowej EAO z dotychczasowej realizacji tych konkluzji ${ }^{47}$. Natomiast podczas posiedzenia w dniach 17-18 listopada 2014 r. Rada do Spraw Zagranicznych uchwaliła nowe konkluzje polityczne. Po raz pierwszy w tak wyrazisty sposób zwróciła w nich uwage na zagrożenia dla bezpieczeństwa Europy wynikające z konfliktów międzynarodowych w bezpośrednim i dalszym sąsiedztwie Unii Europejskiej (m.in. na Ukrainie, w Iraku,

45 Posiedzenie Konferencji Międzyparlamentarnej ds. Wspólnej Polityki Zagranicznej i Bezpieczeństwa oraz Wspólnej Polityki Bezpieczeństwa i Obrony w dniach 3-4 kwietnia 2014 r. w Atenach. Konkluzje, Ateny, 3-4 IV 2014 r., s. 3.

46 Tamże, s. 4-5.

47 Posiedzenie Rady do Spraw Zagranicznych $w$ dniu 24 czerwca 2014 r. Komunikat prasowy, Bruksela, 24 VI 2014 r., 11198/14, s. 9; Posiedzenie Rady do Spraw Zagranicznych w dniu 22 lipca 2014 r. Komunikat prasowy, Bruksela, 22 VII 2014 r., 12091/14, s. 22. 
Syrii, Libii i Sahelu). W ślad za tym wskazała na pilną potrzebę koordynacji działań podejmowanych w ramach polityk odpowiedzialnych za bezpieczeństwo zewnętrzne i wewnętrzne Unii, w szczególności współpracę pomiędzy organami, misjami i operacjami WPBiO a organami PWBiS (m.in. Europolem, Frontexem i Cepolem). Tylko takie skoordynowane podejście gwarantowało - jej zdaniem - skuteczną walkę z nielegalną imigracją, terroryzmem, działalnością przestępczą zagranicznych bojowników, inną przestępczością zorganizowaną, a także cyberprzestępczością. Istotne znaczenie winna mieć również w tym kontekście współpraca Unii Europejskiej z Interpolem ${ }^{48}$.

Rada uchwaliła także ramy polityki Unii Europejskiej w dziedzinie cyberobrony, przewidujące m.in. rozwój zdolności państw członkowskich w tym zakresie; usprawnienie ochrony sieci łączności związanych z WPBiO, wykorzystywanych przez podmioty Unii; zwiększanie możliwości szkolenia, kształcenia i ćwiczeń, a także zacieśnianie współpracy $\mathrm{z}$ odpowiednimi partnerami międzynarodowymi. Ponadto przyjęła ramy polityki Unii w zakresie systematycznej i długoterminowej współpracy w dziedzinie obronności, które - zgodnie z konkluzjami Rady Europejskiej z grudnia 2013 r. winny być spójne z obecnymi procesami planowania $N A T O^{49}$.

W końcu Rada wskazała także na fakt, że państwa członkowskie, wspierane przez EAO, poczyniły znaczne postępy w realizacji czterech kluczowych projektów zatwierdzonych przez Radę Europejską w grudniu 2013 r., czyli w zakresie rozwijania zdolności samolotów do tankowania w powietrzu, rozpoczęcia prac przygotowawczych do produkcji nowej generacji satelitów telekomunikacyjnych, współpracy w dziedzinie cyberbezpieczeństwa, a także stworzenia bezzałogowych systemów powietrznych w latach 2020-2025. Ponownie wyraziła ona potrzebę zwiększenia skuteczności wspólnej polityki bezpieczeństwa i obrony przez rozwój EDTIB oraz wykorzystanie wszystkich możliwości, jakie stwarzają przepisy art. 44 TUE w sprawie zasad powierzania grupie państw członkowskich zadań prowadzenia misji cywilnych i wojskowych Unii Europejskiej ${ }^{50}$.

Zgodnie z konkluzjami Rady Europejskiej z grudnia 2013 r. Rada do Spraw Zagranicznych zwróciła się do nowej wysokiej przedstawiciel Unii, Federiki Mogherini, aby w 2015 r. w ścisłej współpracy z Komisją Europejską oraz po konsultacjach z państwami członkowskimi przedstawiła jej ona sprawozdanie na temat wyzwań i możliwości stojących przed Unią Europejską w dziedzinie bezpieczeństwa zewnętrznego ${ }^{51}$.

48 Posiedzenie Rady do Spraw Zagranicznych w dniach 17-18 listopada 2014 r. Komunikat prasowy, Bruksela, 18 XI 2014 r., 15573/14, s. 16, 19.

Tamże, s. 18.

Tamże, s. 19-20.

5131 III 2015 r. ministrowie obrony państw Trójkąta Weimarskiego, obradujący w Poczdamie, wystosowali wspólny list do Mogherini w sprawie kierunków dalszego rozwoju WPBiO. 3 IV tegoż roku podczas spotkania we Wrocławiu podobny list wysłali do wysokiej przedstawiciel Unii ministrowie spraw zagranicznych Polski, Niemiec i Francji. Opowiedzieli się w nim za dalszym wzmacniania WPBiO, która winna stanowić sedno wspólnej polityki zagranicznej i bezpieczeństwa Unii Europejskiej. Por.: Ministerstwo Spraw Zagranicznych RP, Szefowie dyplomacji Trójkąta Weimarskiego we Wroctawiu, 3 IV 2015 r., s. 1, [online] http://www.msz.gov.pl/pl/, 25 IV 2016; Ministerstwo Spraw Zagranicznych RP, Trójkąt Weimarski, s. 1-2, [online] http://www.msz. gov.pl/pl/, 25 IV 2016; 
Zapowiedziała również, że w maju 2015 r. uchwali nowe konkluzje dotyczące wspólnej polityki bezpieczeństwa i obrony, aby umożliwić Radzie Europejskiej przedstawienie w czerwcu 2015 r. dalszych wytycznych w tej dziedzinie ${ }^{52}$.

Również w 2015 r. debatę na temat zmian we wspólnej polityce bezpieczeństwa i obrony otwarło posiedzenie Konferencji Międzyparlamentarnej ds. Wspólnej Polityki Zagranicznej i Bezpieczeństwa oraz Wspólnej Polityki Bezpieczeństwa i Obrony. Odbyło się ono w dniach 4-6 marca 2015 r. w Rydze. W przyjętych wówczas konkluzjach Konferencja podkreśliła konieczność przedefiniowania roli i interesów UE $w$ zakresie bezpieczeństwa z powodu nieustannie zmieniającego się środowiska bezpieczeństwa ${ }^{53}$. Wskazała na nowe wyzwania dla bezpieczeństwa europejskiego, wynikające z tzw. wojny czwartej generacji, czyli wojny hybrydowej, stanowiącej połączenie niekonwencjonalnych i konwencjonalnych metod militarnych, elementów wojny cybernetycznej, gospodarczej i informacyjnej oraz presji politycznej. Wezwała rządy państw członkowskich do wzmocnienia odporności Unii Europejskiej na zagrożenia wynikające z wojny hybrydowej poprzez tworzenie lepszych synergii cywilno-wojskowych oraz wyspecjalizowanych zdolności państw cztonkowskich, w tym komunikacji strategicznej i zabezpieczenia granic zewnętrznych Unii ${ }^{54}$. Uczestnicy posiedzenia wyrazili również opinię, że tylko $w$ drodze prawdziwej i intensywnej wspótpracy Unia Europejska będzie w stanie zbudować wtasne zdolności obronne w celu wzmocnienia swojej suwerenności. W związku z tym pozytywnie ocenili oni projekty wspólnego pozyskiwania i wykorzystywania zdolności wojskowych (pooling and sharing), zrealizowane ze wsparciem EAO oraz Komitetu Wojskowego UE, a obejmujące wspomniane wyżej wykorzystanie zdalnie sterowanych bezzałogowych systemów powietrznych, rządowej łączności satelitarnej, tankowania w powietrzu oraz rozwijania zdolności w zakresie cyberobrony. Oświadczyli również, że grupy bojowe UE oraz siły reagowania NATO (NRF) i połączone siły zadaniowe bardzo wysokiej gotowości NATO (VJTF) należy traktować jako struktury komplementarne, a nie konkurencyjne. Zwrócili uwagę na potrzebę przyjęcia modułowej koncepcji rozmieszczenia grup bojowych $w$ celu stworzenia bardziej elastycznych europejskich zdolności, które będą mogty być wykorzystywane w operacjach przewidujacych szybka interwencje $i$ stabilizacje $w$ obszarach kryzysowych. W ślad za tym zaapelowali do Rady Europejskiej z propozycją znalezienia konstruktywnego i trwatego rozwiązania kwestii finansowania rozmieszczenia grup bojowych UE na podstawie postanowień mechanizmu ATHENA ${ }^{55}$.

18 maja 2015 r. do debaty włączyła się Rada do Spraw Zagranicznych, uchwalając nowe konkluzje w sprawie wspólnej polityki bezpieczeństwa i obrony. Zasadniczo Rada doprecyzowywała w nich postanowienia uzgodnione już w listopadzie 2014 r.,

52 Posiedzenie Rady do Spraw Zagranicznych $w$ dniach 17-18 listopada 2014 r. ..., s. 20.

53 Posiedzenie Konferencji Międzyparlamentarnej ds. Wspólnej Polityki Zagranicznej i Bezpieczeństwa oraz Wspólnej Polityki Bezpieczeństwa i Obrony w dniach 4-6 marca 2015 r. w Rydze. Konkluzje, Ryga, 4-6 III 2015 r., s. 6.

54 Tamże, s. 8.

55 Tamże, s. 7. 
choć wskazywała także na konieczność realizacji przez Unię Europejską nowych zadań. Po raz pierwszy definiowała ona nową europejską strategię bezpieczeństwa zewnętrznego Unii jako dokument określający interesy, priorytety i cele Unii, a także instrumenty, za pomocą których Unia powinna przeciwdziałać stojącym przed nią zagrożeniom i wyzwaniom. Wspólna polityka bezpieczeństwa i obrony miałaby odgrywać coraz ważniejszą rolę w działaniach zewnętrznych Unii Europejskiej. Natomiast bezpieczeństwo zewnętrzne winno być jeszcze mocniej niż dotychczas powiązane z bezpieczeństwem wewnętrznym. Do katalogu wyzwań i zagrożeń stojących przed Unią Europejską Rada do Spraw Zagranicznych zaliczała nie tylko, jak dotąd, nielegalną imigrację, terroryzm, przestępczość zorganizowaną, działalność przestępczą zagranicznych bojowników, przemyt i handel ludźmi, bezpieczeństwo energetyczne i cybernetyczne, ale także zarządzanie granicami oraz wojnę hybrydową. W odróżnieniu od poprzednich konkluzji w analizowanym dokumencie wskazywano również nieco bardziej precyzyjnie na możliwość zacieśnienia współpracy między organami, misjami i operacjami WPBiO oraz organami PWBiS na podstawie ramowych umów o wspólpracy, podpisanych pomiędzy ESDZ a Frontexem, Europolem i Europejskimi Siłami Żandarmeriii ${ }^{56}$. Po raz pierwszy zapowiedziano także włączenie do planowania i realizacji WPBiO kwestii dotyczących praw człowieka, prawa humanitarnego i uchodźczego, w tym ochrony osób cywilnych oraz dzieci w konfliktach zbrojnych ${ }^{57}$. W świetle wzrastającego zagrożenia $\mathrm{w}$ postaci wykorzystywania przez podmioty publiczne i niepubliczne strategii oraz operacji hybrydowych Rada zobowiązała wysoką przedstawiciel Unii do przedłożenia jej do końca 2015 r. ramowych propozycji umożliwiających ich zwalczanie za pomocą m.in. takich instrumentów, jak: obrona cybernetyczna, wczesne ostrzeganie, komunikacja strategiczna, a także odpowiednie unijne wewnętrzne i zewnętrzne strategie polityczne ${ }^{58}$.

Odnosząc się do trzech działań priorytetowych przyjętych przez Radę Europejską w grudniu 2013 r., Rada do Spraw Zagranicznych wskazała również na nowe zadania stojące przed Unią Europejską. Jeśli chodzi o zwiększenie skuteczności, widoczności i oddziaływania wspólnej polityki bezpieczeństwa i obrony, Rada zatwierdziła koncepcję zarządzania kryzysowego dla ewentualnej operacji, której celem byłoby przeciwdziałanie przemytowi imigrantów przez Morze Śródziemne, a tym samym walka z kryzysem imigracyjnym w Unii ${ }^{59}$. W ten sposób Rada do Spraw Zagranicznych realizowała

56 Council of the European Union. Outcome of proceedings, Council conclusions on CSDP, Brussels, 18 V 2015, 8971/15, s. 2-3.

57 Tamże, s. 9.

58 Tamże, s. 3.

59 Tamże, s. 6. Z zadowoleniem przyjęła ona również rozpoczęcie negocjacji w sprawie nabycia przez Centrum Satelitarne Unii Europejskiej nowej generacji sprzętu do obrazowania o wysokiej rozdzielczości dla rządowej łączności satelitarnej, a także zachęciła Komisję Europejską, Europejską Służbę Działań Zewnętrznych, Europejską Agencję Obrony i państwa członkowskie do dalszej współpracy w zakresie obserwacji i śledzenia obiektów kosmicznych oraz obrazowania o wysokiej rozdzielczości w oparciu o zasoby państw członkowskich i globalny system nawigacji satelitarnej (GNSS). Rada przyjęła także przedstawiony w tym samym dniu wspólny komunikat wysokiej przedstawiciel Unii i Komisji Europejskiej zatytułowany Budowanie zdolności na rzecz wsparcia ochrony i rozwoju - umożliwienie partnerom zapobiegania kryzysom i zarządzania nimi. Por.: tamże, s. 8, 11. Zawierał on m.in. nowe 
postanowienia nadzwyczajnego posiedzenia Rady Europejskiej z 23 kwietnia 2015 r. Biorąc pod uwagę drugie działanie priorytetowe, czyli wzmocnienie zasobów i zdolności cywilnych oraz wojskowych Unii Europejskiej, Rada do Spraw Zagranicznych wezwała państwa członkowskie do realizacji jej zaleceń zawartych w konkluzjach z listopada 2014 r., a dotyczących systematycznej i długoterminowej współpracy w dziedzinie obronności. Natomiast w odniesieniu do trzeciego działania priorytetowego, czyli rozwoju przemysłu obronnego, pozytywnie oceniła dotychczasowy proces konsultacji z udziałem m.in. Komisji Europejskiej, EAO oraz państw członkowskich, mający na celu opracowanie wniosku dotyczącego programu badawczego w dziedzinie zbrojeń, który miałby być finansowany w ramach wieloletnich ram finansowych w latach 2021-2027. Badania takie winny spełniać następujące warunki: uwzględniać specyfikę sektora obrony; być prowadzone na każdym etapie w ścisłej konsultacji z państwami członkowskimi oraz stanowić uzupełnienie krajowych programów badawczych, a także być zgodne i spójne z działalnością EAO ${ }^{60}$. Podkreślając znaczenie EDTIB dla rozwoju przemysłu obronnego Unii Europejskiej, Rada zachęciła do rozważenia możliwości powiązania rozwoju inwestycji w tej dziedzinie z programem zwiększenia wzrostu gospodarczego i inwestycji, zaproponowanym przez przewodniczącego Komisji Europejskiej Jeana-Claude'a Junckera ${ }^{61}$.

Ponadto Rada do Spraw Zagranicznych zobowiązała wysoką przedstawiciel Unii oraz Komisję Europejską do opracowania do połowy 2016 r., w konsultacji z państwami członkowskimi, nowej strategii bezpieczeństwa zewnętrznego Unii Europejskiej. Oznaczało to odroczenie o rok terminu jej opracowania. Ta nowa strategia winna się opierać na zaangażowaniu wszystkich organów oraz instrumentów wspólnej polityki zagranicznej i bezpieczeństwa, wspólnej polityki bezpieczeństwa i obrony oraz polityk należących do przestrzeni wolności, bezpieczeństwa i sprawiedliwości z poszanowaniem ich odpowiednich podstaw prawnych, gtównych celów i procedur decyzyjnych ${ }^{62}$.

propozycje dotyczące oceny i monitorowania oraz metodologii zarządzania ryzykiem, wzmocnienia koordynacji działań między instytucjami Unii Europejskiej a państwami członkowskimi w ramach WPBiO, a także umocnienia synergii pomiędzy wspólną polityką bezpieczeństwa i obrony oraz polityką rozwojową, w szczególności tymi jej instrumentami, które dotyczą afrykańskich państw zagrożonych terroryzmem, upadających lub upadłych. Por.: Komisja Europejska, Wysoki Przedstawiciel Unii do spraw Zagranicznych i Polityki Bezpieczeństwa, Wspólny komunikat do Parlamentu Europejskiego i Rady „Budowanie zdolności na rzecz wsparcia ochrony i rozwoju - umożliwienie partnerom zapobiegania kryzysom i zarzadzania nimi”, Strasburg, 28 IV 2015 r., JOIN(2015) 17 wersja ostateczna, s. 1-13. Council of the European Union. Outcome of proceedings, Council conclusions on CSDP, s. 12-15.

${ }^{61} 15$ VII 2014 r. w Parlamencie Europejskim Jean-Claude Juncker, jako kandydat na przewodniczącego Komisji Europejskiej, zapowiedzial program inwestycji na rzecz zatrudnienia i wzrostu gospodarczego w Unii w ciągu najbliższych trzech lat. 26 XI 2014 r. Komisja Europejska przedstawiła ten program w komunikacie skierowanym do Parlamentu Europejskiego, Rady Unii Europejskiej, Europejskiego Banku Centralnego, Europejskiego Komitetu Ekonomiczno-Społecznego, Komitetu Regionów i Europejskiego Banku Inwestycyjnego. Por.: Komisja Europejska, Komunikat Komisji do Parlamentu Europejskiego, Rady, Europejskiego Banku Centralnego, Europejskiego Komitetu Ekonomiczno-Spotecznego, Komitetu Regionów oraz Europejskiego Banku Inwestycyjnego „Plan inwestycyjny dla Europy”, Bruksela, 26 XI 2014 r., $\operatorname{COM(2014)~} 903$ wersja ostateczna, s. 1-23.

62 Council of the European Union. Outcome of proceedings, Council conclusions on CSDP, s. 8. 
Rada zapowiedziała również, że do listopada 2016 r. przedstawi kolejne konkluzje polityczne, które winny umożliwić Radzie Europejskiej przyjęcie dalszych wytycznych ${ }^{63}$.

Oceniając konkluzje Rady do Spraw Zagranicznych z 18 maja 2015 r., warto zauważyć, że wiele spośród zawartych w nich postanowień zostało sformułowanych mało precyzyjnie lub jedynie potwierdzało wcześniejsze uzgodnienia. Deklarując uchwalenie nowej koncepcji szybkiego reagowania Unii Europejskiej, Rada nie precyzowała np., na czym dokładnie miałoby ono polegać, lecz zalecała jedynie szersze i bardziej modułowe podejście do wykorzystania unijnych grup bojowych. Z zadowoleniem przyjęła sam fakt podjęcia konsultacji z państwami członkowskimi w sprawie ewentualnego skorzystania z przepisów art. 44 TUE w realizacji misji petersberskich, ale z drugiej strony nie była w stanie wskazać na żadne konkretne uzgodnienia w tej dziedzinie. Inicjatywa ta budziła bowiem liczne zastrzeżenia lub napotykała nawet brak woli politycznej niektórych rządów państw członkowskich. Najważniejszy był wszakże fakt, że podczas tego posiedzenia zapadła ostateczna decyzja o odroczeniu o rok terminu uchwalenia nowej strategii bezpieczeństwa zewnętrznego Unii Europejskiej.

Trzy dni później, 21 maja 2015 r., Parlament Europejski uchwalił kolejną rezolucję poświęconą wdrażaniu wspólnej polityki bezpieczeństwa i obrony. Wyraził on ponownie opinię, że konflikty zbrojne w bezpośrednim i dalszym sąsiedztwie Unii Europejskiej, w szczególności wojna na wschodniej Ukrainie, terrorystyczna działalność tzw. Państwa Islamskiego oraz kryzys libijski, po raz pierwszy od powstania EPBiO/ WPBiO pod koniec lat $90 . \mathrm{XX} \mathrm{w}^{64}$ zagrozity na niespotykaną dotąd skalę bezpieczeństwu Unii Europejskiej. Szczególne zaniepokojenie musiał - jego zdaniem - wzbudzać fakt, że Unia nie jest w stanie dziatać w sposób skoordynowany i odgrywać decydującej roli $\mathrm{w}$ walce $\mathrm{z}$ tymi zagrożeniami, ogranicza się natomiast zbyt często do polegania na inicjatywach któregośz państw cztonkowskich lub ich grupy bądźn na sojuszach ad hoc, w których odgrywa tylko role marginalna lub wspierajaca. Parlament Europejski wyraził ubolewanie, że impuls polityczny nadany WPBiO w konkluzjach Rady Europejskiej w grudniu 2013 r. nie przetożyt się na zacieśnienie wspótpracy i na szybkie wprowadzenie istotnych praktycznych środków odpowiadająych zadeklarowanym celom. Tym bardziej zatem nakazem chwili stawało się opracowanie nowej europejskiej strategii bezpieczeństwa zewnętrznego Unii Europejskiej ${ }^{65}$.

Autorzy rezolucji równie krytycznie ocenili zasady finansowania WPBiO, zwłaszcza ponoszenia kosztów transportu strategicznego grup bojowych, jak i realizację przez

63 Tamże, s. 16.

64 Pierwotnie wspólna polityki bezpieczeństwa i obrony nosiła nazwę europejskiej polityki bezpieczeństwa i obrony. Postanowiono ją utworzyć na mocy deklaracji Rady Europejskiej z 4 VI 1999 r., przyjętej w Kolonii. Na mocy traktatu nicejskiego zadania związane z europejską polityką bezpieczeństwa i obrony, realizowane dotąd przez Unię Zachodnioeuropejską, zostały powierzone Unii Europejskiej (art. 17 ust. 1-3 TUE). Natomiast na podstawie traktatu lizbońskiego wspólna polityka bezpieczeństwa i obrony uzyskała status traktatowy (art. 42 ust. 1-7 TUE).

65 Parlament Europejski, Rezolucja Parlamentu Europejskiego z dnia 21 maja 2015 r. wsprawie wdrażania wspólnejpolityki bezpieczeństwa i obrony (na podstawie sprawozdania rocznego Rady dla Parlamentu Europejskiego na temat wspólnej polityki zagranicznej i bezpieczeństwa (14605/1/2012-2013/2105(INI)), P7_TA(2014)2220, s. 3. 
Unię Europejską misji cywilnych i wojskowych. Zgłosili postulat, aby w czasie najbliższego posiedzenia Rady Europejskiej w czerwcu 2015 r. zachęcić oporne państwa cztonkowskie do przeznaczania większych środków na obronę oraz skoncentrować starania na tych obszarach zarzadzania kryzysowego, w których UE mogtaby wnieść faktyczna wartość dodana ${ }^{66}$. Zarzucili niektórym z nich brak konstruktywnego podejścia do grup bojowych, w szczególności do kwestii finansowania ich transportu do teatrów działań ze środków mechanizmu ATHENA ${ }^{67}$. Zwrócili uwagę, że misje cywilne i wojskowe od samego początku były zbyt często powoływane z myśla o zapewnieniu widoczności Unii podczas danego kryzysu, a nie jako strategiczny instrument uruchamiany po dogtęnej analizie i szczegótowym planowaniu ${ }^{68}$. Ponadto wezwali oni wysoką przedstawiciel Unii tudzież rządy państw członkowskich do implementacji przepisów dotyczących ustanowienia funduszu początkowego (art. 41 ust. 3 TUE) i stałej współpracy strukturalnej (art. 46 ust. 6 TUE), a także określenia zasad uruchamiania klauzuli sojuszniczej (art. 42 ust. 7 TUE) ${ }^{69}$.

66 Tamże, s. 4-5.

67 Tamże, s. 8.

68 Tamże, s. 6. Od 2003 r. Unia Europejska wysłała łącznie ponad trzydzieści misji cywilnych i wojskowych do kilkunastu państw Europy, Afryki, Bliskiego Wschodu, a nawet Azji. Średnio było to 2,5 operacji rocznie, przy czym każdorazowo przeważały misje cywilne. Przykładowo w 2015 r. Unia prowadziła jedenaście misji cywilnych oraz pięć misji wojskowych na trzech kontynentach. Szerzej na temat misji cywilnych i wojskowych Unii Europejskiej por.: A. Ciupiński, Wspólna Polityka Bezpieczeństwa i Obrony Unii Europejskiej. Geneza, rozwój, funkcjonowanie, Warszawa 2013; Misje cywilne Unii Europejskiej, red. B. Przybylska-Maszner, Poznań 2010; Operacje wojskowe Unii Europejskiej w Afryce, red. B. Przybylska-Maszner, Poznań 2014. Szerzej na temat systemu reagowania kryzysowego Unii Europejskiej por.: System reagowania kryzysowego Unii Europejskiej. Struktura, charakter, obszary, red. J. Gryz, Toruń 2009.

69 Parlament Europejski, Rezolucja Parlamentu Europejskiego z dnia 21 maja 2015 r. ..., s. 8. Do momentu uchwalenia przez Parlament Europejski analizowanej rezolucji zapadły cztery istotne decyzje implementacyjne Rady Europejskiej lub Rady Unii Europejskiej dotyczące wspólnej polityki zagracznej i bezpieczeństwa oraz wspólnej polityki bezpieczeństwa i obrony. 1 XII 2009 r. Rada Europejska, uwzględniając przepisy art. 18 ust. 1 TUE, mianowała Catherine Ashton na stanowisko wysokiej przedstawiciel Unii ds. zagranicznych i polityki bezpieczeństwa. 26 VII 2010 r. Rada Unii Europejskiej na mocy art. 27 ust. 3 TUE podjęła decyzję precyzującą organizację i zasady funkcjonowania ESDZ. 12 VII 2011 r. Rada Unii Europejskiej na podstawie art. 45 ust. 2 TUE podjęła decyzję określającą statut, siedzibę i zasady funkcjonowania EAO. 24 VI 2014 r. Rada Unii Europejskiej w oparciu o art. 222 ust. 3 TFUE przyjęła decyzję ustanawiającą zasady i procedury dotyczące stosowania przez Unię Europejska klauzuli solidarności. Jednak w dalszym ciągu brak było decyzji Rady Unii Europejskiej w sprawie ustanowienia stałej współpracy strukturalnej (art. 46 ust. 1-2 TUE) oraz wniosku wysokiej przedstawiciel Unii i decyzji Rady Unii Europejskiej dotyczących utworzenia funduszu początkowego Unii Europejskiej (art. 41 ust. 3 TUE). W przypadku stałej współpracy strukturalnej winę ponosiły państwa członkowskie, ponieważ zgodnie z art. 46 ust. 1-2 TUE to one winny notyfikować Radzie Unii Europejskiej i wysokiej przedstawiciel Unii swój zamiar wzięcia udziału w takiej współpracy. Natomiast w wypadku funduszu początkowego odpowiedzialność spadała na wysoką przedstawiciel Unii, która nie złożyła dotąd - zgodnie z art. 41 ust. 3 TUE - wniosku w sprawie przyjęcia przez Radę Unii Europejskiej decyzji o ustanowieniu takiego funduszu. Por.: J.J. Węc, Proces implementacji traktatu lizbońskiego w latach 2009-2014, „Politeja” 2015, nr 2 (35), s. 342-345, 368-370, [online] http://dx.doi.org/10.12797/Politeja.12.2015.35.24. 
Implementacja pierwszego z postanowień TUE ułatwiłaby rozwiązanie - przynajmniej w pewnym zakresie - problemu finansowania niektórych inicjatyw podejmowanych w ramach WPBiO, zwłaszcza działań przygotowawczych do realizacji misji petersberskich o charakterze cywilnym i militarnym (art. 41 ust. 3 TUE). Wdrożenie przepisów o stałej współpracy strukturalnej umożliwiłoby natomiast m.in. tworzenie wspólnych jednostek wojskowych czy organizowanie wspólnych zakupów uzbrojenia (art. 46 ust. 1-2) 70 $^{7}$ Jeśli chodzi natomiast o klauzulę sojuszniczą, to art. 42 ust. 7 TUE nie zawiera przepisu upoważniającego Radę Europejską lub Radę Unii Europejskiej do jej stosowania. Ponieważ zgodnie z art. 13 ust. 2 TUE każda instytucja Unii Europejskiej działa $w$ granicach uprawnień przyznanych jej na mocy Traktatów, zgodnie z procedurami, na warunkach i w celach w nich określonych, oznacza to, że wyłącznie państwa członkowskie mogą decydować o udzieleniu sobie wzajemnej pomocy, i to - w tym przypadku - jednomyślnie ${ }^{71}$.

Jak wspomniano wyżej, wbrew zapowiedziom sprzed dwóch lat w 2015 r. nie udało się opracować nawet projektu nowej strategii bezpieczenstwa zewnętrznego Unii Europejskiej. W tej sytuacji Rada Europejska w konkluzjach przyjętych podczas posiedzenia w dniach 25-26 czerwca 2015 r. wyznaczyła trzy kierunki działań w obszarach bezpieczeństwa zewnętrznego i wewnętrznego Unii Europejskiej. Po pierwsze, ponownie zobowiązała wysoką przedstawiciel Unii, aby w ścisłej współpracy z państwami członkowskimi przygotowała do czerwca 2016 r. globalna strategię UE w zakresie polityki zagranicznej $i$ bezpieczeństwa. Dokument ten miałby być przedmiotem obrad Rady Europejskiej właśnie w czerwcu tegoż roku. Po drugie, zaleciła kontynuację prac nad trzema priorytetowymi działaniami Unii Europejskiej we wspólnej polityce bezpieczeństwa i obrony, uzgodnionymi w konkluzjach Rady Europejskiej z grudnia 2013 r., a rozwiniętymi w konkluzjach politycznych Rady do Spraw Zagranicznych z maja 2015 r. Po trzecie, nakazała kontynuację działań na rzecz opracowania odnowionej strategii bezpieczeństwa wewnętrznego Unii Europejskiej w oparciu o Europejską agendę bezpieczeństwa Komisji Europejskiej oraz konkluzje polityczne Rady ds. Wymiaru Sprawiedliwości i Spraw Wewnętrznych z 16 czerwca 2015 r., a także wytyczne dotyczące walki z terroryzmem uzgodnione w lutym 2015 r. $^{72}$

Gdy posiedzenie Rady Europejskiej w czerwcu 2015 r. zakończyło się fiaskiem, a w każdym razie nie doszło wówczas do uchwalenia nowej strategii bezpieczeństwa zewnętrznego Unii Europejskiej, Konferencja Międzyparlamentarna, obradująca w dniach 5-6 września 2015 r. w Luksemburgu, wyraziła z tego powodu głębokie ubolewanie. Zarzuciła wówczas szefom państw lub rządów brak ambicji, który jest niepokojacym przejawem braku woli politycznej mimo zagrożeń i wyzwań, przed którymi stanęła obecnie Unia. Zaapelowała również do Rady Europejskiej o ponowne zajęcie

70 Por.: tenże, Dynamika..., s. 439.

71 Szerzej na ten temat por.: tenże, Traktat Lizboński..., s. 342-343; tenże, Proces implementacji..., s. 369-370.

72 Posiedzenie Rady Europejskiej w dniach 25-26 czerwca 2015 r. Konkluzje, Bruksela, 26 VI 2015 r., EUCO 22/15, s. 5-6. 
się sprawami bezpieczeństwa nie później niż w czerwcu 2016 r., a także o zorganizowanie pogtębionej dyskusji na temat niedociagnięć $w$ realizacji zobowiazań podjętych przez niq w czerwcu 2013 r. Krytycznie oceniła fakt, że Komisja Europejska nie zrealizowała zadań określonych w konkluzjach Rady Europejskiej z grudnia 2013 r., dotyczących w szczególności stworzenia systemu bezpieczeństwa dostaw obejmującego całą Unię Europejską, opracowania dokumentu na temat transakcji międzyrządowych oraz Zielonej Księgi w sprawie kontroli aktywów. Zaapelowała do rządów państw członkowskich o rozpoczęcie procedury implementacji przepisów art. 42 ust. 6 TUE (stała współpraca strukturalna) oraz do Rady Unii Europejskiej o wykorzystanie możliwości wynikających z postanowień art. 44 TUE (powierzenie misji lub operacji w ramach WPBiO grupie państw członkowskich). Zwróciła się również do ESDZ o rozważenie przez Dyrekcję ds. Zarządzania Kryzysowego i Planowania sprawy docelowego wprowadzenia alternatywnych procedur zarządzania kryzysowego dla misji Unii Europejskiej podejmowanych zgodnie z art. 42 ust. 6 TUE oraz art. $44 \mathrm{TUE}^{73}$.

Konferencja Międzyparlamentarna zaapelowała także do wysokiej przedstawiciel Unii o przygotowanie do połowy 2016 r. „ambitnej” globalnej strategii bezpieczeństwa zewnętrznego Unii Europejskiej. Strategia ta winna wzmocnić bezpieczeństwo Unii poprzez powiązanie jej zarówno z pozostałymi działaniami zewnętrznymi, jak i politykami należącymi do przestrzeni wolności, bezpieczeństwa i sprawiedliwości ${ }^{74}$. Ponadto powinna ona wytyczyć strategiczne ramy dla najważniejszych aktualnie wyzwań w dziedzinie polityki bezpieczeństwa, związanych zarówno z imperialnymi działaniami Rosji w Europie Wschodniej oraz zagrożeniami wynikającymi z niestabilności w regionie Bliskiego Wschodu, Morza Śródziemnego i Afryki, jak też z przekrojowych wyzwań strategicznych, w tym m.in. terroryzmu, zagrożeń hybrydowych, państw niestabilnych lub upadających, zagrożeń cybernetycznych, zmian klimatycznych, a także przemytu ludzi ${ }^{75}$.

Gdy 17 listopada 2015 r., cztery dni po atakach terrorystycznych w Paryżu, rząd francuski podczas posiedzenia Rady do Spraw Zagranicznych powołał się na klauzulę sojuszniczą, uzyskał pełne poparcie ze strony wszystkich państw członkowskich Unii Europejskiej $^{76}$. W ślad za tym 21 stycznia 2016 r. Parlament Europejski uchwalił rezolucję, w której wyraził opinię, że państwa cztonkowskie UE mają w stosunku do Francji obowiązek udzielenia pomocy i wsparcia przy zastosowaniu wszelkich dostępnych im środków, zgodnie z artykutem 51 Karty Narodów Zjednoczonych ${ }^{77}$. Jednocześnie wyraził

Posiedzenie Konferencji Międzyparlamentarnej ds. Wspólnej Polityki Zagranicznej i Bezpieczeństwa oraz Wspólnej Polityki Bezpieczeństwa i Obrony w dniach 5-6 września 2015 r. w Luksemburgu. Konkluzje, Luksemburg, 5-6 IX 2015 r., s. 10-12.

74 Tamże, s. 2-3.

75 Tamże, s. 3.

76 Posiedzenie Rady do Spraw Zagranicznych w dniach 16-17 listopada 2015 r. Komunikat prasowy, Bruksela, 17 XI 2015 r., s. 1, [online] http://www.consilium.europa.eu/pl/meetings/fac/2015/11/16-17/, 25 IV 2016.

77 Parlament Europejski, Rezolucja Parlamentu Europejskiego z dnia 21 stycznia 2016 r. w sprawie klauzuli wzajemnej obrony (art. 42 ust. 7 TUE) (2015/3034/RSP), P8_TA-PROV(2016)0019, s. 12. W projekcie rezolucji z 13 I 2016 r. znalazła się nawet propozycja, aby art. 42 ust. 7 TUE mógł być uznawany 
ubolewanie, że po tym, jak powołano się po raz pierwszy na klauzulę sojuszniczą, Unia Europejska nie dysponowała żadnymi stosownymi analizami czy wytycznymi, lecz była zdana jedynie na doraźne środki, zarządzanie i współpracę ${ }^{78}$. W ślad za tym Parlament Europejski wezwał Radę Europejską do nadania dynamiki dalszemu rozwojowi klauzuli wzajemnej obrony, zaś Radę do Spraw Zagranicznych i rządy państw członkowskich do pilnego opracowania i przyjęcia ram polityki, które pomoga w ukierunkowaniu realizacji postanowień art. 42 ust. 7 TUE ibęcda przewidywaty ramy czasowe, klauzulęprzegladowa oraz mechanizmy monitorowania ${ }^{79}$.

\section{UWAGI KOŃCOWE}

Należy podkreślić, że impuls polityczny, jaki mogły nadać Unii Europejskiej konkluzje Rady Europejskiej z grudnia 2013 r. w dziedzinie wspólnej polityki bezpieczeństwa i obrony, nie został wystarczająco wykorzystany. Przyczyną był nie tylko kryzys zadłużeniowy strefy euro czy brak woli politycznej państw członkowskich do wykorzystania potencjału, jaki stwarzał w $\mathrm{WPBiO}$ traktat lizboński, lecz przede wszystkim kryzys imigracyjny, który uwidaczniał się już od 2011 r., ale w 2015 r. przybrał rozmiary zagrażające podstawom egzystencji Unii Europejskiej. Okazało się, że Unia nie dysponuje wystarczającymi środkami operacyjnymi, przemysłowymi czy militarnymi do odgrywania decydującej roli w zarządzaniu kryzysami międzynarodowymi, zapobieganiu takim kryzysom, a tym bardziej ich przezwyciężaniu zgodnie z przepisami art. 21 ust. 1-3 TUE.

za unijny odpowiednik art. 5 NATO. Por.: Parlament Europejski, Rezolucja Parlamentu Europejskiego w sprawie klauzuli wzajemnej obrony (art. 42 ust. 7 TUE) (2015/3034/RSP). Projekt B8-0043/2016, s. 2.

78 Do klauzuli sojuszniczej Parlament Europejski odniósł po raz pierwszy w specjalnej rezolucji z 22 XI 2012 r. Zaproponował w niej uruchomienie klauzuli sojuszniczej nie na mocy art. 42 ust. 7 TUE, ale na podstawie art. 32 TUE. Artykuł ten przewidywał konsultacje państw członkowskich w duchu solidarności na forum Rady Europejskiej i Rady Unii Europejskiej w sprawie wszelkich kwestii polityki zagranicznej i bezpieczeństwa stanowiących przedmiot ogólnego zainteresowania, ale bez uszczerbku dla przystugujacego każdemu państwu cztonkowskiemu prawa do równolegtego organizowania wtasnej obrony. Parlament zwrócił się nawet wówczas w tej sprawie do wysokiej przedstawiciel Unii, aby zaproponowata [ona] praktyczne ustalenia i wytyczne $w$ celu zapewnienia efektywnych dziatań $w$ odpowiedzi na powotanie sięprzez którekolwiek z państw cztonkowskich na klauzulę o wzajemnej obronie, a także analizę roli, jaka odegrać powinny instytucje UE w sytuacji powotania się na tę klauzulę. W opinii Parlamentu zobowiąanie do zapewnienia sobie pomocy $i$ wsparcia byłoby również wyrazem politycznej solidarności między państwami cztonkowskimi. Por.: Parlament Europejski, Rezolucja Parlamentu Europejskiego $z$ dnia 22 listopada 2012 r. w sprawie klauzul wzajemnej obrony i solidarności UE: wymiaru politycznego i operacyjnego (2012/2223/(INI)), P7_TA-PROV(2012)0456, s. 6.

79 Parlament Europejski, Rezolucja Parlamentu Europejskiego z dnia 21 stycznia 2016 r..., s. 13. W projekcie z 13 I 2016 r. znalazło się wezwanie skierowane do wysokiej przedstawiciel Unii, Rady do Spraw Zagranicznych oraz Komisji Europejskiej do przedstawienia stosownych propozycji praktycznych ustaleń i wytycznych gwarantujących zbiorowa i skuteczna reakcje, w przypadku gdy państwo cztonkowskie powota się na klauzulę wzajemnej obrony. Por.: Parlament Europejski, Rezolucja Parlamentu Europejskiego... Projekt B8-0043/2016, s. 4 . 
Osiągnięcia Unii Europejskiej w dziedzinie wspólnej polityki bezpieczeństwa i obrony w analizowanym okresie wypadają zatem nader skromnie. Nie udało się przede wszystkim zrealizować podstawowego celu, jakim było uchwalenie nowej strategii bezpieczeństwa zewnętrznego Unii. Zaniedbania w zakresie implementacji przepisów traktatu lizbońskiego były nadal duże (stała współpraca strukturalna, fundusz początkowy). Nie podjęto także żadnej decyzji politycznej w sprawie możliwości korzystania z przepisów niezawierających upoważnienia implementacyjnego (klauzula sojusznicza oraz art. 42 ust. 3 TUE). Jedynymi istotnymi osiągnięciami w omawianym okresie było uchwalenie strategii Unii Europejskiej w zakresie bezpieczeństwa morskiego ( 24 czerwca 2014 r.) oraz dokumentów towarzyszących (plan działania), a także przyjęcie ram polityki Unii w dziedzinie cyberobrony (18 listopada 2014 r.) oraz ram polityki Unii w zakresie systematycznej i długoterminowej współpracy w dziedzinie obronności (18 listopada 2014 r.). Spośród dokumentów politycznych na uwagę zasługują ponadto komunikat Komisji Europejskiej w sprawie bardziej konkurencyjnego i wydajnego sektora obronności i bezpieczeństwa (24 lipca 2013 r.), wspólny komunikaty Komisji Europejskiej i wysokiej przedstawiciel Unii na temat kompleksowego podejścia Unii do zewnętrznych konfliktów i sytuacji kryzysowych (11 grudnia 2013 r.), wspólny komunikat Komisji Europejskiej i wysokiej przedstawiciel Unii na temat budowania zdolności na rzecz wsparcia ochrony i rozwoju w celu umożliwienia partnerom zapobiegania kryzysom i zarządzania nimi (28 kwietnia 2015 r.), a także konkluzje polityczne Rady do Spraw Zagranicznych w sprawie wspólnej polityki bezpieczeństwa i obrony z 23 lipca 2013 r., 18 listopada 2014 r. oraz 18 maja 2015 r.

\section{BIBLIOGRAFIA}

Council Decision 2004/197/CFSP of 23 February 2004 establishing a mechanism to administer the financing of the common costs of European Union operations having military or defence implications, Official Journal L, 2004, nr 63.

Council of the European Union. Outcome of proceedings, Council conclusions on CSDP, Brussels, 18 V 2015, 8971/15.

Dyrektywa Parlamentu Europejskiego i Rady 2009/43/WE z dnia 6 maja 2009 r. w sprawie uproszczenia warunków transferów produktów zwiazanych z obronnościq we Wspólnocie, „Dziennik Urzędowy Unii Europejskiej” L, 2009, nr 146.

Dyrektywa Parlamentu Europejskiego i Rady 2009/81/WE z dnia 13 lipca 2009 r. w sprawie koordynacji procedur udzielania niektórych zamówień na roboty budowlane, dostawy i ustugi przez instytucje lub podmioty zamawiające $w$ dziedzinach obronności i bezpieczeństwa i zmieniająca dyrektywy 2004/17/WE i 2004/18/WE, „Dziennik Urzędowy Unii Europejskiej” L, 2009, nr 216.

Instytucjonalne relacje UE-NATO, [online] http://www.psz.pl/.

Komisja Europejska, Komunikat Komisji do Parlamentu Europejskiego, Rady, Europejskiego Komitetu Ekonomiczno-Spotecznego i Komitetu Regionów „W kierunku bardziej konkurencyjne- 
go i wydajnego sektora obronności i bezpieczeństwa”, Bruksela, 24 VII 2013 r., COM(2013) 542 wersja ostateczna.

Komisja Europejska, Komunikat Komisji do Parlamentu Europejskiego, Rady, Europejskiego Banku Centralnego, Europejskiego Komitetu Ekonomiczno-Spotecznego, Komitetu Regionów oraz Europejskiego Banku Inwestycyjnego „Plan inwestycyjny dla Europy”, Bruksela, 26 XI 2014 r., $\operatorname{COM}(2014) 903$ wersja ostateczna.

Komisja Europejska, Wysoki Przedstawciel Unii Europejskiej do spraw Zagranicznych i Polityki Bezpieczeństwa, Wspólny komunikat do Parlamentu Europejskiego i Rady „Kompleksowe podejście UE do zewnętrznych konfliktów i sytuacji kryzysowych”, Bruksela, 11 XII 2013 r., JOIN(2013) 30 wersja ostateczna.

Komisja Europejska, Wysoki Przedstawiciel Unii do spraw Zagranicznych i Polityki Bezpieczeństwa, Wspólny komunikat do Parlamentu Europejskiego i Rady „Budowanie zdolności na rzecz wsparcia ochrony i rozwoju - umożliwienie partnerom zapobiegania kryzysom $i$ zarzadzania nimi”, Strasburg, 28 IV 2015 r., JOIN(2015) 17 wersja ostateczna.

Ministerstwo Spraw Zagranicznych RP, Relacje UE-NATO, [online] https://www.msz.gov.pl/ $\mathrm{pl} /$.

Ministerstwo Spraw Zagranicznych RP, Szefowie dyplomacji Trójkąta Weimarskiego we Wroctawiu, 3 IV 2015 r., [online] http://www.msz.gov.pl/pl/.

Ministerstwo Spraw Zagranicznych RP, Trójkąt Weimarski, [online] http://www.msz. gov.pl/ $\mathrm{pl} /$.

Parlament Europejski, Rezolucja Parlamentu Europejskiego w sprawie klauzuli wzajemnej obrony (art. 42 ust. 7 TUE) (2015/3034/RSP). Projekt B8-0043/2016.

Parlament Europejski, Rezolucja Parlamentu Europejskiego z dnia 12 września 2013 r. w sprawie struktur wojskowych UE: stan obecny i przyszte perspektywy (2012(2319)INI)), P7_TA(2013)0381.

Parlament Europejski, Rezolucja Parlamentu Europejskiego z dnia 21 listopada 2013 r. w sprawie wdrażania wspólnej polityki bezpieczeństwa i obrony (na podstawie sprawozdania rocznego Rady dla Parlamentu Europejskiego na temat wspólnej polityki zagranicznej i bezpieczeństwa (14605/1/2012-2013/2105(INI)), P7_TA(2013)0513.

Parlament Europejski, Rezolucja Parlamentu Europejskiego z dnia 21 maja 2015 r. w sprawie wdrażania wspólnej polityki bezpieczeństwa i obrony (na podstawie sprawozdania rocznego Rady dla Parlamentu Europejskiego na temat wspólnej polityki zagranicznej i bezpieczeństwa (14605/1/2012-2013/2105(INI)), P7_TA(2014)2220.

Parlament Europejski, Rezolucja Parlamentu Europejskiego z dnia 21 stycznia 2016 r. w sprawie klauzuli wzajemnej obrony (art. 42 ust. 7 TUE) (2015/3034/RSP), P8_TA-PROV(2016) 0019.

Parlament Europejski, Rezolucja Parlamentu Europejskiego z dnia 22 listopada 2012 r. w sprawie klauzul wzajemnej obrony i solidarności UE: wymiaru politycznego $i$ operacyjnego (2012/2223/(INI)), P7_TA-PROV(2012)0456.

Posiedzenia Rady do Spraw Zagranicznych w dniach 18-19 listopada 2013 r. Komunikat prasowy, Bruksela, 19 XI 2013 r., 16364/13.

Posiedzenia Rady do Spraw Zagranicznych w dniu 23 lipca 2012 r. Komunikat prasowy, Bruksela, 23 VII 2012 r., 12800/1/12 REV 1. 
Posiedzenie Konferencji Międzyparlamentarnej ds. Wspólnej Polityki Zagranicznej i Bezpieczeństwa oraz Wspólnej Polityki Bezpieczeństwa i Obrony w dniach 4-6 września 2013 r. w Wilnie. Konkluzje, Wilno, 4-6 IX 2013 r.

Posiedzenie Konferencji Międzyparlamentarnej ds. Wspólnej Polityki Zagranicznej i Bezpieczeństwa oraz Wspólnej Polityki Bezpieczeństwa i Obrony w dniach 3-4 kwietnia 2014 r. w Atenach. Konkluzje, Ateny, 3-4 IV 2014 r.

Posiedzenie Konferencji Międzyparlamentarnej ds. Wspólnej Polityki Zagranicznej i Bezpieczeństwa oraz Wspólnej Polityki Bezpieczeństwa i Obrony w dniach 4-6 marca 2015 r. w Rydze. Konkluzje, Ryga, 4-6 III 2015 r.

Posiedzenie Konferencji Międzyparlamentarnej ds. Wspólnej Polityki Zagranicznej i Bezpieczeństwa oraz Wspólnej Polityki Bezpieczeństwa i Obrony w dniach 5-6 września 2015 r. w Luksemburgu. Konkluzje, Luksemburg, 5-6 IX 2015 r.

Posiedzenie Rady do Spraw Zagranicznych w dniach 16-17 listopada 2015 r. Komunikat prasowy, Bruksela, 17 XI 2015 r., [online] http://www.consilium.europa.eu/pl/meetings/ $\mathrm{fac} / 2015 / 11 / 16-17 /$.

Posiedzenie Rady do Spraw Zagranicznych w dniach 17-18 listopada 2014 r. Komunikat prasowy, Bruksela, 18 XI 2014 r., 15573/14.

Posiedzenie Rady do Spraw Zagranicznych w dniu 22 lipca 2014 r. Komunikat prasowy, Bruksela, 22 VII 2014 r., 12091/14.

Posiedzenie Rady do Spraw Zagranicznych w dniu 24 czerwca 2014 r. Komunikat prasowy, Bruksela, 24 VI 2014 r., 11198/14.

Posiedzenie Rady Europejskiej w Brukseli w dniach 11-12 grudnia 2008 r. Konkluzje prezydencji, Bruksela, 13 II 2009 r., 16616/07 (załącznik 2).

Posiedzenie Rady Europejskiej w dniach 13-14 grudnia 2012 r. Konkluzje, Bruksela, 14 XII 2012 r., EUCO 205/12.

Posiedzenie Rady Europejskiej w dniach 19-20 grudnia 2013 r. Konkluzje, Bruksela, 20 XII 2013 r., EUCO 217/13.

Posiedzenie Rady Europejskiej w dniach 25-26 czerwca 2015 r. Konkluzje, Bruksela, 26 VI 2015 r., EUCO 22/15.

Rada Unii Europejskiej, Europejska Strategia Bezpieczeństwa „Bezpieczna Europa w lepszym świecie”, Urząd Publikacji Unii Europejskiej, Luksemburg 2009.

Regulamin Konferencji Międzyparlamentarnej ds. Wspólnej Polityki Zagranicznej i Bezpieczeństwa oraz Wspólnej Polityki Bezpieczeństwa i Obrony, [online] http://oide.sejm.gov.pl/.

Spotkanie Rady Europejskiej w Brukseli w dniach 11-12 grudnia 2003 r. Konkluzje prezydencji, Bruksela, 11-12 XII 2003 r., 16616/07.

Cianciara A.K., Partnerstwo Wschodnie 2009-2014. Geneza, funkcjonowanie, uwarunkowania, Warszawa 2014.

Ciupiński A., Wspólna Polityka Bezpieczeństwa i Obrony Unii Europejskiej. Geneza, rozwój, funkcjonowanie, Warszawa 2013.

Ciupiński A., Zdolności wojskowe Unii Europejskiej. Perspektywy grup bojowych, „Rocznik Integracji Europejskiej” 2014, nr 8, [online] http://dx.doi.org/10.14746/rie.2014.8.8.

Lindstrom G., Enter the EU Battlegroups, Paris 2007, Chaillot Papers, 97. 
Misje cywilne Unii Europejskiej, red. B. Przybylska-Maszner, Poznań 2010.

Olszewski P., Reforma strategii bezpieczeństwa Unii Europejskiej jako nowe otwarcie w relacjach transatlantyckich. Koncepcja i perspektywy, [w:] System euroatlantycki w wielobiegunowym tadzie międzynarodowym, red. J.M.Fiszer, P. Olszewski, Warszawa 2013, System Euroatlantycki w Wielobiegunowym Świecie i Jego Perspektywy, 6.

Operacje wojskowe Unii Europejskiej w Afryce, red. B. Przybylska-Maszner, Poznań 2014.

System reagowania kryzysowego Unii Europejskiej. Struktura, charakter, obszary, red. J. Gryz, Toruń 2009.

Terlikowski M., Stan i perspektywy partnerstwa UE i NATO, „Biuletyn PISM” 2010, nr 106.

Unia Europejska $w$ regionie śródziemnomorskim. Między polityka wspólna a interesami państw cztonkowskich, red. J. Zając, Warszawa 2014.

Wstronę nowej europejskiej strategii bezpieczeństwa. Food for thought, Biuro Bezpieczeństwa Narodowego, Warszawa 2012, [online] http://www.bbn.gov.pl.

Węc J.J., Dynamika wspólnej polityki bezpieczeństwa i obrony po wejściu w życie traktatu lizbońskiego, [w:] Bezpieczeństwo międzynarodowe. Polska, Europa, Świat. Księga Jubileuszowa dedykowana Profesorowi Ryszardowi Ziębie z okazji czterdziestolecia pracy naukowej, red. J. Zając, A. Włodkowska-Bagan, M. Kaczmarski, Warszawa 2015.

Węc J.J., Pierwsza polska prezydencja w Unii Europejskiej. Uwarunkowania, procesy decyzyjne, osiagnięcia i niepowodzenia, Kraków 2012, Societas, 44.

Węc J.J., Proces implementacji traktatu lizbońskiego w latach 2009-2014, „Politeja” 2015, nr 2 (35), [online] http://dx.doi.org/10.12797/Politeja.12.2015.35.24.

Węc J.J., Traktat Lizboński. Polityczne aspekty reformy ustrojowej Unii Europejskiej w latach 20072015, Kraków 2016, Societas, 36.

Węc J.J., W poszukiwaniu nowej strategii bezpieczeństwa zewnętrznego Unii Europejskiej, „Krakowskie Studia Międzynarodowe” 2015, nr 2.

Prof. dr hab. Janusz Józef WĘC - profesor zwyczajny nauk humanistycznych w zakresie historii powszechnej najnowszej i stosunków międzynarodowych. Kierownik Katedry Studiów nad Procesami Integracyjnymi w Instytucie Nauk Politycznych i Stosunków Międzynarodowych Uniwersytetu Jagiellońskiego w Krakowie. Autor ponad 200 publikacji naukowych wydanych w kraju i za granica, w tym 18 monografii i syntez, na temat ustroju Wspólnot Europejskich i Unii Europejskiej, integracji europejskiej i pozaeuropejskiej, stosunków polsko-niemieckich, najnowszej historii Niemiec, a także niemieckiego systemu politycznego. Ostatnio wydane monografie: Traktat Lizboński. Polityczne aspekty reformy ustrojowej Unii Europejskiej w latach 2007-2015, Kraków 2016; Pierwsza polska prezydencja w Unii Europejskiej. Uwarunkowania, procesy decyzyjne, osiagnięcia i niepowodzenia, Kraków 2012; Spór o ksztatt ustrojowy Wspólnot Europejskich $i$ Unii Europejskiej w latach 1950-2010. Między idea ponadnarodowości a wspótpraca międzyrządową. Analiza politologiczna, Kraków 2012; Sozialliberale Ostpolitik: Die FDP und der Warschauer Vertrag. Die Haltung der FDP gegenüber den Verhandlungen mit Polen über den Warschauer Vertrag vom 7. Dezember 1970, Potsdam 2011. 